
\title{
25 Research Square \\ Reduced methane oxidizing activity by sediment methanotrophs in shallow coastal zones with high methane emissions
}

Elias Broman ( $\nabla$ elias.broman@su.se )

Stockholm University https://orcid.org/0000-0001-9005-5168

Xiaole Sun

Stockholm University

Christian Stranne

Stockholm University

Marco G Salgado

Stockholm University

Stefano Bonaglia

Stockholm University

Marc Geibel

Stockholm University

Alf Norkko

University of Helsinki

Christoph Humborg

Stockholm University

Francisco J.A Nascimento

Stockholm University

\section{Research}

Keywords: oceanic methane emissions, coastal zone, sediment methanotrophs

Posted Date: February 13th, 2020

DOI: https://doi.org/10.21203/rs.2.17360/v2

License: (c) (i) This work is licensed under a Creative Commons Attribution 4.0 International License.

Read Full License

Version of Record: A version of this preprint was published on July 7th, 2020. See the published version at https://doi.org/10.3389/fmicb.2020.01536. 


\section{Abstract}

Background Coastal zones are transitional areas between land and sea where large amounts of organic and inorganic carbon compounds are recycled by microbes. Especially shallow zones near land have been shown to be the main source for oceanic methane $(\mathrm{CH} 4)$ emissions. Water depth has been predicted as the best explanatory variable, which is related to $\mathrm{CH} 4$ ebullition, but exactly how sediment methanotrophic bacteria mediates these emissions along water depth is unknown. Here, we investigated the activity of methanotrophs in the sediment of shallow coastal zones with high $\mathrm{CH} 4$ emissions within a depth gradient from 10-45 m. Field sampling consisted of collecting sediment slices from eight stations along a coastal gradient ( $0-4 \mathrm{~km}$ from land) in the coastal Baltic Sea. We combined real-time measurements of surface water $\mathrm{CH} 4$ concentrations, acoustic detection of $\mathrm{CH} 4$ seeps in the bottom water, and sediment DNA plus RNA sequencing.

Results The relative abundance and $\mathrm{CH} 4$ oxidizing activity (pMMO; particulate methane monooxygenase) of the dominant methanotroph Methylococcales was significantly higher in deeper costal offshore areas (36-45 m water depth) compared to adjacent shallow zones (10-28 m). This was in accordance with the shallow zones having $\mathrm{CH} 4$ concentrations in the surface water, as well as more $\mathrm{CH} 4$ seeps from the sediment. Furthermore, our findings indicate that the low prevalence of Methylococcales and their activity was restrained to the euphotic zone (indicated by PAR data, photosynthesis proteins, and 18S rRNA data of benthic diatoms). This was also indicated by a positive relationship between water depth and the relative abundance of Methylococcales and pMMO.

Conclusions We detected a low relative abundance of methanotrophs and $\mathrm{CH} 4$ oxidizing activity in shallow coastal areas, this can partly explain the difference in $\mathrm{CH} 4$ emissions between shallow and deep coastal areas (and the relationship between $\mathrm{CH} 4$ emission and water depth). Potentially a reduced activity of methanotrophs also facilities the build-up of $\mathrm{CH} 4$ bubbles in the sediment. $\mathrm{CH} 4$ emissions from the study area has previously been calculated to be comparable to that of subarctic lakes, and it is suggested that shallow coastal waters, similarly to inland waters, are hotspots for $\mathrm{CH} 4$ emissions.

\section{Background}

Coastal zones are transitional areas between land and sea where microbes in the water and sediment cycle large amounts of organic and inorganic carbon compounds [1]. Such zones have recently been shown to be the main source for oceanic methane $\left(\mathrm{CH}_{4}\right)$ emissions [2]. $\mathrm{CH}_{4}$ is a potent greenhouse gas that has increased $\sim 2.5$ times in the atmosphere since the industrial revolution [3], and is today at $\sim 1.85$ ppm [4], and contributes to approximately $20 \%$ of tropospheric radiative forcing [5]. Furthermore, the annual atmospheric $\mathrm{CH}_{4}$ concentration measured during 2014-2017 was record high since 1980 [4]. The majority of $\mathrm{CH}_{4}$ emissions are derived from human activities ( 60\%) such as livestock [6], rice paddies [7, 8], hydropower dams [9]te management [10]. However, natural aquatic systems such as inland waters are reported to contribute a significant portion to $\mathrm{CH}_{4}$ emissions (30\% or more) [10-12]. In marine ecosystems, coastal zones have the highest contribution to global $\mathrm{CH}_{4}$ emissions [2, 13], with shallow 
inshore waters closer to land being estimated to have an annual $\mathrm{CH}_{4}$ emission 370 times higher compared to that in the open ocean $[12,14,15]$. Globally, shallow water depths in coastal zones are linked to higher $\mathrm{CH}_{4}$ emissions [2], but environmental predictors have been unable to explain this relationship [2]. It is therefore possible that biological mechanisms are partly able to explain the discrepancy between coastal shallow and deeper areas. However, this has not been fully investigated and would help to increase the understanding of the controls of $\mathrm{CH}_{4}$ cycling in coastal areas.

The cycling of $\mathrm{CH}_{4}$ in natural aquatic ecosystems is driven by microbial consumption and oxidative processes [16]. In brief, the majority of $\mathrm{CH}_{4}$ is produced in anoxic zones in sediments as a result of the reduction of e.g. $\mathrm{CO}_{2}$, acetate, or methanol by anaerobic methanogenic archaea [17]. Large parts of the produced $\mathrm{CH}_{4}$ diffuses upwards in the sediment and is oxidized to $\mathrm{CO}_{2}$ by anaerobic methanotrophic archaea (ANME) [18], anaerobic methanotrophic bacteria [19], and eventually by aerobic methanotrophic bacteria in the oxic sediment surface or the water column [20]. These aerobic methanotrophic bacteria thrive on produced $\mathrm{CH}_{4}$, and have traditionally been divided into two types: Type I belonging to the Gammaproteobacteria family Methylococcales, and Type II belonging to the Alphaproteobacteria family Methylocystaceae and Beijerinckiaceae [21]. Both types use the enzyme methane monooxygenase (MMO) to oxidize $\mathrm{CH}_{4}$, and are able to utilize either the particulate form (pMMO, i.e. bound to the intracellular membrane) and/or the soluble form (sMMO, i.e. enzyme complex in the cytoplasma) [21]. The importance of methanotrophic bacteria to limit $\mathrm{CH}_{4}$ emission has previously been shown, e.g. Bornemann M, Bussmann I, Tichy L, Deutzmann J, Schink B and Pester M [22] used pMMO primers (subunit A, $p m o A$ ) and clone-libraries to identify methanotrophs (taxonomic order Methylococcales) in the pelagic area of Lake Constance, and found that these bacteria contributed substantially to $\mathrm{CH}_{4}$ removal in the bottom water directly above the sediment surface. Bacterial members belonging to e.g. the class Methylococcales are ubiquitous [23], and metagenome plus metatranscriptome analysis have shown that they dominate aerobic $\mathrm{CH}_{4}$ oxidation in wetland soil [23], and are important in removing $\mathrm{CH}_{4}$ escaping from benthic $\mathrm{CH}_{4}$ seeps [24]. Methanotrophs are therefore essential key players in regulating $\mathrm{CH}_{4}$ emission to the atmosphere from aquatic environments. Although methanotrophs play a key role in $\mathrm{CH}_{4}$ cycling and emission to the atmosphere, it is still not fully understood what environmental factors control these populations in aquatic sediments.

Major environmental factors controlling methanogenesis in the coastal zone include temperature and labile organic matter load that influence bacterial activity and oxygen availability in the sediment $[25,26]$. $\mathrm{CH}_{4}$ produced by methanogens are oxidized in the sediment or water column by methanotrophs. Main factors shown to control methanotrophy include $\mathrm{CH}_{4}$ availability and oxygen availability [27], and differences in adaptation among methanotrophic bacteria have been shown as a response to varying $\mathrm{pH}$, salinity, and oxygen concentration [28]. Laboratory studies have also shown that methanotrophs and their activity are stimulated when other heterotrophic bacteria are present $[29,30]$. Ammonium $\left(\mathrm{NH}_{4}{ }^{+}\right)$and $\mathrm{CH}_{4}$ can be oxidized by both ammonia oxidizing and methanotrophic bacteria, although methanotrophs oxidize $\mathrm{CH}_{4}$ more efficiently and vice versa [31]. High concentrations of $\mathrm{NH}_{4}{ }^{+}$have, thus, been reported to 
have an inhibitory effect on methanotrophic activity [32,33]. Additionally, controlled experimental studies have investigated the role of light availability in mediating methanotrophic activity, but showed contrasting results with both inhibition [34,35] and stimulation being reported [36]. Despite this, there is a knowledge gap on the underlying reasons as to why higher $\mathrm{CH}_{4}$ emission to the surface waters occur in shallow coastal areas. It has been suggested that shallow areas have well-mixed waters where $\mathrm{CH}_{4}$ can reach the surface waters easily, and bubbles from $\mathrm{CH}_{4}$ seeps in the seafloor can quickly escape to the atmosphere [12]. However, what role $\mathrm{CH}_{4}$ oxidation has in regulating such emissions in these shallow coastal areas and what environmental factors determine $\mathrm{CH} 4$ oxidizer activity is unknown. Such knowledge is critical to our understanding of the contribution of coastal ecosystems to global $\mathrm{CH}_{4}$ budgets.

The aim of the study was to investigate and elucidate why $\mathrm{CH}_{4}$ emission is higher in shallow inshore coastal zones compared to adjacent deeper offshore areas. We tested the following hypotheses: a) the relative abundance of methanotrophs is higher in shallow inshore sediments where previous studies have found high concentrations of $\mathrm{CH}_{4}$ in the water column; b) relative abundance and activity of methanotrophs are positively related to concentrations of surface water $\mathrm{CH}_{4}$ and number of $\mathrm{CH}_{4}$ seabed seeps; and c) bottom water oxygen and pore water $\mathrm{NH}_{4}{ }^{+}$concentrations regulate methanotrophic activity in the sampled sediments.

\section{Results}

In this study, a multidisciplinary team of scientists aboard the research vessel (R/V) Electra participated on a cruise conducted in the Western Gulf of Finland during June 2017 and September 2018. Field sampling consisted of collecting sediment slices (top 0-2 cm) from eight stations along a coastal gradient (0-4 km from land, 10-45 m water depth) in the Storfjärden bay, Tvärminne, Finland ( $n=3$ per station; Fig. 1 and Table 1). The stations were divided into four offshore sites (stations 5, 7, 10, 13; 36- 45 $m$ deep) and four inshore sites (stations $11,12,15,16 ; 10-28 \mathrm{~m}$ deep). Sediment was extracted for metagenomic DNA and RNA sequencing to identify $\mathrm{CH}_{4}$-related microbial populations and active metabolism. During the 2018 sampling campaign this data was coupled to i) real-time measurements of $\mathrm{CH}_{4}$ in the 0.5-1.0 m water surface (first presented in Humborg C, Geibel MC, Sun X, McCrackin M, Mörth C-M, Stranne C, Jakobsson M, Gustafsson B, Sokolov A, Norkko A and Norkko J [37]), and ii) acoustic data of the seafloor and bottom water to identify $\mathrm{CH}_{4}$ seeps. Furthermore, CTD casts in the study area were used to collect water column profiles of light (PAR) and oxygen concentrations.

Water column parameters. During the sampling campaigns salinity ranged $6.5-7.0 \mathrm{ppt}$, with higher salinity in the bottom water. In the surface water salinity did not differ between the inshore and offshore stations during sampling. Temperature ranged $3.4-8.9^{\circ} \mathrm{C}\left(2017\right.$ early June) and $6.02-15.82^{\circ} \mathrm{C}(2018$ late September), with higher temperatures in the surface water. CTD profiles of the water column from twelve during the 2018 sampling campaign locations inside the study area showed that photosynthetically active radiation (PAR) light reached a water depth of $28 \mathrm{~m}$ at sites $<30 \mathrm{~m}$ water depth, and the inshore 
stations would therefore have been illuminated (Additional File 1: Fig. S1). The bottom water was oxic with oxygen concentrations between 7.6-8.6 ml/l in the study area as measure during 2018 (Additional File 1: Fig. S1).

$\mathrm{CH}_{4}$ concentrations in the surface water. $\mathrm{CH}_{4}$ concentrations in the surface water were higher in the inshore shallow stations close to land (23.4-40.6 nM, $n=4$ stations) compared to the offshore areas (16.2-23.4 nM; $n=3$ stations, Fig. 1 and Table 2).

Alpha and beta diversity. In the 0-2 cm sediment surface prokaryotic alpha diversity ranged between 5.3-6.2 (Shannon's H, 16S rRNA gene DNA 2018 data) with no difference between inshore and offshore stations (Kruskal-Wallis test). NMDs of Bray-Curtis beta diversity showed that the offshore stations 7, 10, and 13 clustered differently compared to inshore stations 11, 12, 16, and 15 (PERMANOVA 9999 permutations, $F=8.5, P=0.0001$ for the whole model; Additional File 1: Fig. S2). A full list of the prokaryotic classifications and sequence counts is available in Additional File 2: Data S1.

Methanotrophic bacteria in inshore and offshore sediments. Gammaproteobacteria had the highest relative abundance of the prokaryotic community in the $0-2 \mathrm{~cm}$ sediment surface when comparing phyla and Proteobacteria classes between stations (Fig. 2A). In the metagenome 16 rRNA gene data the relative abundance of Gammaproteobacteria ranged between 30-51 \% for all stations (Fig. 2A). The relative

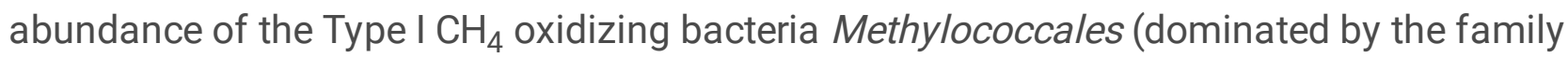
Methylomonaceae, with majority of sequences (up to $79.7 \%$ ) aligning to Methyloprofundus; Additional File 2: Data S1) was significantly higher in stations located offshore when compared to the more shallow inshore stations (16S rRNA gene DNA data, Kruskal-Wallis tests, $\mathrm{df}=1, H=19.7, P=0.000009$ (2017 DNA data), $\mathrm{df}=1, H=18.1, P=0.000021$ (2018 DNA); Fig. 2B). In the DNA data Methylococcales had a relative abundance up to $4.98 \%$ of the whole microbial community (Additional File 2: Data S1). Furthermore, taxonomic classification of all metagenomic sequences against the NCBI RefSeq genome database (Additional File 2: Data S2) showed that Methylococcales was attributed a higher relative proportion of reads in the offshore stations when compared to the inshore stations (Kruskal-Wallis tests, 2017 DNA data, $H=17.4, P=0.000030 ; 2018$ DNA data, $\mathrm{df}=1, H=14.8, P=0.000116$; Fig. 3A). Similarly, based on mapping RNA reads against metagenome assembled $p m o A B$ genes (Additional File 2: Data S3), more RNA reads were mapped in the offshore stations compared to the inshore stations (KruskalWallis test, $\mathrm{df}=1, H=14.8, P=0.000121$; Fig. 3B and Table 2). To test that the higher relative abundance of methanotrophs were not an effect of sequencing depth the count data of Methylococcales 16S rRNA gene sequences, all other $16 \mathrm{~S}$ rRNA gene sequences, and total library size was tested with DESeq2. The results showed that in the offshore stations the Methylococcales 16S rRNA gene counts had a log2 fold change of 10.5 (for year 2017) and 10.9 (year 2018) compared to the inshore stations. In contrast, the counts for other $16 \mathrm{~S}$ rRNA gene sequences and the total library size had both a log2 fold change of 0.1 for both years (Additional File 1: Fig. S3).

$\mathrm{CH}_{4}$ concentrations measured in the 0.5-1.0 $\mathrm{m}$ water surface showed a negative relationship with the 16S rRNA gene relative abundance of Methylococcales in the sediment, with lower $\mathrm{CH}_{4}$ concentrations in 
the offshore stations (Fig. 4A) where Methylococcales activity was higher. Furthermore, $\mathrm{CH}_{4}$ concentration measured in the water column during the sampling campaign 2018 correlated negatively with the relative abundance of Methylococcales for the same-year DNA data (rho $=-0.768, P=0.000047$, $n=21$ ). That Methylococcales was associated with offshore sites further away from the coast was also indicated by positive correlations with water depth (2018 DNA data, rho $=0.818, P=0.000006$; 2017 DNA data, rho $=0.740, P=0.000036$ ). In addition to a higher relative abundance of Methylococcales, RNA transcripts attributed to the protein family $\mathrm{AMO} / \mathrm{pMMO}$ also correlated negatively with measured concentrations of $\mathrm{CH}_{4}$ (based on classifying all paired-end merged RNA sequences, rho $=-0.760, P=$ $0.000064, n=21$; See Additional File 2: Data S4 for all protein classifications; Fig. 4). RNA transcripts attributed to $\mathrm{AMO} / \mathrm{pMMO}$ were also significantly higher in the offshore stations $(F D R<0.05$, test between all stations individually; Fig. 4B and Table 1), while functional genes in the metagenome attributed to $\mathrm{AMO} / \mathrm{pMMO}$ were available at all stations with little difference in CPM values (counts per million sequences) (1429-1652 CPM; Table 2), showing that the potential to oxidize $\mathrm{CH}_{4}$ was available at all sites. The soluble form of MMO was not detected in the RNA transcript dataset (Additional File 2: Data S4). AMO/pMMO sequences were classified against the UniProtKB/Swiss-Prot database to separate $\mathrm{AMO}$ and $\mathrm{pMMO}$ sequences. The results showed a large difference in $\mathrm{PMMO}$ CPM values between the offshore stations ( $8742 \pm 2342 \mathrm{CPM}$, one standard deviation shown) compared to the shallower inshore stations (58 $\pm 175 \mathrm{CPM}$, Kruskal-Wallis test, $\mathrm{df}=1, H=14.7, P=0.000124 ;$ Fig. 5). These pMMO sequences were affiliated with the reference species Methylococcus capsulatus in the UniProtKB/SwissProt database. That methanotrophy was higher in the offshore stations compared to inshore was also supported with quantitative reverse transcription PCR (RT-qPCR) based on RNA samples and degenerate pmoA primers (Additional File 1: Data S3). The offshore stations had $0.003257 \pm 0.001067 \mathrm{NRQ}$ (normalized relative quantification) compared to the inshore stations with $0.000066 \pm 0.000094 \mathrm{NRQ}$ (One-Way ANOVA, $F_{(1,19)}=108.0, P=0.000000003$; Fig. 6 and Table 2; results from non-degenerate primers are shown in Additional File 2: Fig. S4; NRQ is based on pmoA transcripts numbers normalized for $16 \mathrm{~S}$ rRNA).

Because light has been indicated to inhibit $\mathrm{CH}_{4}$ oxidation we also analysed the amount of RNA transcripts attributed to proteins in the Gene Ontology (GO) category Photosynthesis (Table 2 and Additional File 2: Data S4). Photosynthesis proteins in the sediment surface had a negative correlation with both the relative abundance of Methylococcales (2018 data,rho $=-0.615, P=0.003$ ), and $\mathrm{AMO} / \mathrm{pMMO}$ enzymes (rho $=-0.760, \mathrm{P}=0.00006, n=21$ ). Photosynthesis proteins were also negatively correlated with water depth (rho $=-0.676, P=0.0008, n=21$; Additional File 1: Fig. S5). Moreover, $18 \mathrm{~S}$ rRNA data of diatoms with a higher relative abundance of benthic genera such as Amphora and Nitzschia in the inshore stations provides further indication that these stations were euphotic (Additional File 1: Fig. S6). This in accordance with the PAR data that indicated the inshore areas to be illuminated while offshore bottom zones were in darkness. A full list of proteins can be found in Additional File 2: Data S4 (RNA) and Additional File 2: Data S6 (DNA). 
Our results clearly show that Methylococcales were the major methanotroph active in our sediments, while other methanotrophic bacteria were found to be absent in the DNA dataset. This included the Type II methanotrophic families Methylocystaceae and Beijerinckiaceae (belonging to Alphaproteobacteria), the Verrucomicrobia family Methylacidiphilaceae, and the NC10 phylum known to contain anaerobic methanotrophic bacteria (Additional File 2: Data S1).

Pore water ammonium concentrations. $\mathrm{NH}_{4}{ }^{+}$analyses showed that the pore water concentration of $\mathrm{NH}_{4}{ }^{+}$ was higher in the offshore stations $(308 \pm 59 \mu \mathrm{M})$ compared to the inshore stations (196 $\pm 49 \mu \mathrm{M}$; OneWay ANOVA, $F_{6,14}=33.1, P=0.00000017$, with Tukey post hoc test between stations, $P<0.01$; Table 2). The DNA dataset for both years 2017 and 2018 showed that aerobic ammonia oxidizing bacteria and archaea were present at all sites and had a significantly higher relative abundance in the inshore sites (inshore: $2017,6.9 \pm 1.5 ; 2018,5.4 \pm 1.5 \%$, compared to offshore: $2017,4.2 \pm 1.0 ; 2018,3.4 \pm 1.3 \%$ ) (Kruskal-Wallis tests, 2017, $H=14.9, P=0.00010 ; 2018, H=6.5, P=0.011$; Additional File 1: Fig. S7). However, AMO sequences showed no differences in CPM values between the offshore and inshore stations (196 \pm 90 CPM, Kruskal-Wallis test, $H=0.4, P=0.83$; Fig. 5), suggesting that pore water $\mathrm{NH}_{4}{ }^{+}$ concentrations did not explain the difference in methanotrophic activity between inshore and offshore areas.

Methanotrophic and methanogenic archaea in the sediment. Archaea had a $0-2 \%$ relative abundance in the 0-2 cm sediment (Fig. 2), and methanotrophic archaea (ANME) were not detected in the DNA data for both years (Additional File 2: Data S1). Similarly, methanogenic archaea (e.g. Methanobacteria, Methanomicrobia) were not detected in the DNA samples (Additional File 2: Data S1). These findings suggest that higher $\mathrm{CH}_{4}$ concentrations in the surface water in the study area was unrelated to methanogenic activity in the $0-2 \mathrm{~cm}$ sediment surface (e.g. if surface sediment had been oxygen deficient).

Methane escape from the sediment. Acoustic data of the seafloor and bottom water was collected in the study area during 2018, and $\mathrm{CH}_{4}$ seeps were defined as either trains of bubbles or bubble plumes (Fig. 7). The results showed that the prevalence of $\mathrm{CH}_{4}$ seeps in sediment surface was greater in shallow areas compared to deeper areas (Fig. 8A), further suggesting that $\mathrm{CH}_{4}$ availability did not explain the lower relative abundance of methanotrophs in the inshore stations. Moreover, the amount of $\mathrm{CH}_{4}$ seeps km${ }^{-1}$ was negatively correlated with water depth (Pearson correlation, $r=-0.83, P<0.000001, n=52$; Fig. 8B).

\section{Discussion}

Shallow coastal zones are known to have high $\mathrm{CH}_{4}$ concentrations in the water column compared to deeper waters $[12,14,15]$. This was also indicated by our acoustic data of $\mathrm{CH}_{4}$ seeps and the real-time measurements of $\mathrm{CH}_{4}$ in the surface water [37]. Here we build on these results and hypothesized that: 1) methanotrophic activity (i.e. $\mathrm{CH}_{4}$ cycling) is higher in the shallow inshore stations, and 2) the relative proportion of methanotrophs are positively related to the $\mathrm{CH}_{4}$ concentrations and number of $\mathrm{CH}_{4}$ seabed 
seeps. However, our results presented here instead suggest that these higher $\mathrm{CH}_{4}$ concentrations in shallow coastal zones are partly explained by low methanotrophic activity. This was indicated by the significantly lower relative abundance of $16 \mathrm{~S}$ rRNA gene sequences classified as methanotrophic bacteria, and lower RNA transcripts attributed to $\mathrm{CH}_{4}$ oxidation (pMMO) in the inshore areas (Fig. 9A). The higher abundance of $p m o A$ transcripts in offshore was further confirmed with RT-qPCR data. The metagenome data showed pMMO to be present at all stations (inshore and offshore), further indicating a decreased activity on $\mathrm{CH}_{4}$ oxidation in the inshore areas (rather . A majority of the Methylococcales sequences were classified to the genus Methyloprofundus, an obligate aerobic methanotroph only able to utilize the pMMO pathway [38], which was in accordance to our RNA transcript data. Compared to a previous study measuring $\mathrm{CH}_{4}$ from a $1 \mathrm{~km}$ to $59 \mathrm{~km}$ land-to-sea gradient (Osudar $\mathrm{R}$, Matoušů $A$, Alawi $\mathrm{M}$, Wagner D and Bussmann I [15]) here we also sampled sediment and used fine-scale gradients from the coast $(0-4 \mathrm{~km})$. Our results therefore further imply that shallow coastal zones are hotspots for $\mathrm{CH}_{4}$ emission due to low methanotrophic activity. This is important because microbial aerobic $\mathrm{CH}_{4}$ oxidation has been estimated to account for 50-90\% removal of $\mathrm{CH}_{4}$ before it escapes the sediment surface [27]. Additionally, our findings suggest that a reduced activity of methanotrophs facilitate build-up of $\mathrm{CH}_{4}$ bubbles in the sediment, which helps to further drive high $\mathrm{CH}_{4}$ emissions from shallow coastal zones.

In the study area, water depth strongly correlated with the increase in relative abundance and activity of methanotrophs, with lower amounts of seabed $\mathrm{CH}_{4}$ seeps and $\mathrm{CH}_{4}$ concentrations in the surface water. Abiotic factors that have been shown to affect methanotrophs and their activity along water depth are e.g. salinity [39], oxygen and $\mathrm{CH}_{4}$ availability [27], ammonium concentrations [32, 35], and light [35, 36]. At the time of sampling there was just minor changes in salinity in the studied stations (range 6.5-7.0), compared to previous studies having a factor from freshwater-to-marine salinity $[12,14,15]$. Furthermore, a separate study conducted at the same time in the study area found no significant link between $\mathrm{CH}_{4}$ concentrations in the water and salinity (full details in Humborg C, Geibel MC, Sun X, McCrackin M, Mörth C-M, Stranne C, Jakobsson M, Gustafsson B, Sokolov A, Norkko A and Norkko J [37]) indicating that salinity does not explain the patterns of relative abundance and activity of methanotrophs in our study. The bottom water was oxygenated at all studied stations and was therefore unlikely to be a limiting factor for methanotrophs in the study area. In addition, the real-time measurements and acoustic data of $\mathrm{CH}_{4}$ also showed more $\mathrm{CH}_{4}$ availability in the inshore areas (compared to offshore), and it is therefore unlikely $\mathrm{CH}_{4}$ was a limiting factor inhibiting growth and activity of methanotrophs. The $0-2 \mathrm{~cm}$ sediment surface was sliced and methanogens were not detected in the DNA samples. Considering that methanogenesis occurs in anoxic sediment [17] these findings indicate that the sediment surface was oxygenated by the bottom water in the study area, as also indicated by aerobic ammonia oxidizing bacteria (Additional File 1: Figure S5).

We measured higher pore water $\mathrm{NH}_{4}{ }^{+}$concentrations in the offshore stations, and most of the measured $\mathrm{NH}_{4}{ }^{+}$likely derived from organic matter mineralization in the suboxic and anoxic layers [40] in and below the $0-2 \mathrm{~cm}$ sediment slices. It seems unlikely that methanotrophs might have actively oxidized $\mathrm{NH}_{4}{ }^{+}$. For 
example, the amount of RNA transcripts attributed to pMMO was on average 47 times higher than AMO in the offshore areas. Furthermore, the real-time $\mathrm{CH}_{4}$ measurements and acoustic data showed lower $\mathrm{CH}_{4}$ concentrations in the surface water and less seepages from the offshore sites. If methanotrophs were thriving on $\mathrm{NH}_{4}{ }^{+}$more RNA transcripts for $\mathrm{AMO}$ than pMMO would be expected considering ammonia oxidizing bacteria oxidize $\mathrm{NH}_{4}{ }^{+}$more effectively [31]. Considering that ammonia oxidizing bacteria/archaea [41] had a significantly lower relative abundance in offshore sites, it is more likely that the availability of $\mathrm{CH}_{4}$ was driving growth of methanotrophs in the offshore stations. Moreover, in a laboratory experiment $\mathrm{NH}_{4}{ }^{+}$concentrations below $36 \mathrm{mM}$ have been observed to not influence methanotrophic activity [33] (our highest measurement was $0.4 \mathrm{mM} \mathrm{NH}_{4}^{+}$). In addition, the $\mathrm{NH}_{4}{ }^{+}$data does not explain why methanotrophs had a low relative abundance in the inshore sediments where $\mathrm{NH}_{4}{ }^{+}$ was also available. We hypothesized that $\mathrm{NH}_{4}{ }^{+}$would influence methanotrophy in the studied system along the coastal gradient. Our results instead show that pore water $\mathrm{NH}_{4}{ }^{+}$did not drive inhibition of methanotrophs or methanotrophic activity in the studied system.

Considering that the geochemistry data $\left(\mathrm{CH}_{4}\right.$ water concentrations and $\mathrm{CH}_{4}$ seabed seeps) and biology data (relative abundance of methanotrophic bacteria RNA transcripts attributed to pMMO) both showed a positive relationship with water depth and that the main environmental factor changing along this gradient was light intensity, we suggest that illumination might influence sediment microbial communities. That the inshore stations were euphotic was indicated by 1) the CTD profiles showed that PAR light reached $28 \mathrm{~m}$ in the study area; 2) photosynthesis mRNA data (Fig. 9B) that showed a decrease with water depth; and 3) benthic diatoms such as Amphora and Nitzschia [42] in the inshore stations based on 18S rRNA data (Additional File 1: Fig. S6). Previous studies conducted in a reservoir and pelagic lake water have shown light to inhibit methanotropy and increase $\mathrm{CH}_{4}$ water concentrations in northern South America and central Japan [34,35]. These studies included using bacterial cultures that would remove influencing factors on methanotrophy such as photosynthesis (i.e. producing oxygen) [27]. Moreover, Garcia SL, Szekely AJ, Bergvall C, Schattenhofer M and Peura S [43] investigated the microbial community in a boreal lake with and without snow on the ice cover, and found that the relative abundance of methanotrophic bacteria decreased and $\mathrm{CH}_{4}$ water concentrations increased when the snow cover was removed and illumination increased in the water column. Additionally, the activity of $\mathrm{NH}_{4}{ }^{+}$oxidizing bacteria are known to be inhibited by light availability [44], and this can further explain why light might have an effect on methanotrophs as the enzymes ammonia monooxygenase (AMO) and MMO are highly similar and evolutionary related [45]. However, light has also been observed to stimulate methanotrophic activity in wetland sediments (Florida, USA) [46], and polar lake water (north-west Russia) while investigating bacterial cultures [36]. These contrasting results in the literature could indicate that illumination affects various methanotrophic species differently or indirectly through other ecosystem processes. Further work is needed to investigate if light has a negative effect on methane oxidation in shallow coastal ecosystems. 


\section{Conclusions}

On a global scale $\mathrm{CH}_{4}$ emissions from coastal zones are higher at shallower water depths [2], and we also detected this relationship between water depth and $\mathrm{CH}_{4}$ seeps and $\mathrm{CH}_{4}$ concentrations in the studied costal ecosystem. We detected a lower relative abundance of methanotrophic bacteria and $\mathrm{CH}_{4}$ oxidizing activity in the sediment of shallow coastal areas when compared to adjacent deeper offshore areas. This could partly explain the difference in $\mathrm{CH}_{4}$ emissions in coastal zones, and reduced activity of methanotrophs could also facilitate build-up of $\mathrm{CH}_{4}$ bubbles in the sediment. Here we further increase knowledge with in situ molecular and geochemical data collected in a marine coastal system. We also suggest that light might have a negative effect, directly or indirectly, on the relative abundance and pMMO activity benthic methanotrophy in shallow coastal zones. This is significant because natural aquatic environments are estimated to contribute to at least $30 \%$ of the global $\mathrm{CH}_{4}$ emissions [10]. For example, $\mathrm{CH}_{4}$ emissions from inland waters are known to significantly contribute to the atmospheric budget (estimated to $77 \mathrm{Tg} \mathrm{C} \mathrm{yr}^{-1}$ ) [47]. Humborg C, Geibel MC, Sun X, McCrackin M, Mörth C-M, Stranne C, Jakobsson M, Gustafsson B, Sokolov A, Norkko A and Norkko J [37] calculated a daily sediment fluxwater column $\mathrm{CH}_{4}$ reservoir of $2.5 \mathrm{mmol} \mathrm{m}^{-2}$ (or $30 \mathrm{mg} \mathrm{C} \mathrm{m}^{-2}$ ) in the coastal waters of Tvärminne during September 2018 (same sampling campaign as reported in this study). This is within the range of $\mathrm{CH}_{4}$ emissions reported from subarctic lakes [48], and it is suggested that shallow coastal waters, similarly to inland waters, are hotspots for $\mathrm{CH}_{4}$ emission. Moreover, limited methanotrophic activity could also explain why shallow coastal waters in rapidly changing ecosystems like the East Siberian artic shelf have higher $\mathrm{CH}_{4}$ emissions compared to the deeper offshore water $[49,50]$. Significant $\mathrm{CH}_{4}$ emissions from the artic subsea might therefore only occur in the shallowest parts due to a limited activity of methanotrophs. Our results imply that methanotrophs, rather than solely methanogens, play a key role in shallow coastal zones regulating $\mathrm{CH}_{4}$ emissions. Globally, low methanotrophic activity in the sediment could partly explain the substantial amount of $\mathrm{CH}_{4}$ emissions from shallow inland water bodies and reservoirs [51]. Furthermore, the results suggest that low $\mathrm{CH}_{4}$ oxidizing activity by methanotrophs might explain why shallow parts of the costal rim has higher $\mathrm{CH}_{4}$ emissions. This is an overlooked mechanism that can potentially contribute to explain the dynamics of greenhouse emissions from marine ecosystems.

\section{Methods}

Sediment collection and water column profiles. Sediment slices (top $0-2 \mathrm{~cm}$ ) were collected along coastal gradients (0-4 km, 10-45 m water depth) on board R/V Electra in Storfjärden bay close to the Tvärminne Zoological Station (TZS), Tvärminne, Finland (Fig. 1 and Table 1). Samples were collected during 2017 June 4-5 and 2018 September 20-23. All samples were collected using a GEMAX twin gravity corer in combination with acrylic tubes (height: $80 \mathrm{~cm}$, inner diameter: $80 \mathrm{~mm}$ ). From each core the top 0-2 cm sediment surface layer was sliced into either plastic bags (freezer bags, 2017 sampling) or autoclaved $215 \mathrm{ml}$ polypropylene containers (Noax Lab; 2018 sampling). During June 2017 sediment was collected for DNA extraction from eight stations (due to logistical reasons RNA was not collected), 
while during September 2018 sediment was collected from seven stations for both DNA and RNA extraction ( $n=3$ per station for both years). The stations were divided into four offshore sites (stations 5 , 7, 10, 13; 36-45 m deep) and four inshore sites (stations 11, 12, 15, 16; 10-28 m deep). For the 2018 sampling sediment slices from each station was aseptically homogenised inside the containers and $2 \mathrm{ml}$ sediment transferred into $2 \mathrm{ml}$ cryogenic tubes (VWR), flash frozen in liquid nitrogen, and stored at $-80^{\circ} \mathrm{C}$ at TZS. All collected sediment for DNA was stored at $-20^{\circ} \mathrm{C}$ on the boat until reaching the coast of Sweden (Stora Uttervik, lat. 58.848372, long. 17.541019). The sediment samples on the boat were then transferred into a cooling box filled with ice bars and transported to Stockholm University ( 1 hour). The flash frozen $2 \mathrm{ml}$ sediment for RNA were transported from TZS to Stockholm University on dry ice, and stored again at $-80^{\circ} \mathrm{C}$ until RNA extraction. The DNA data was used to investigate methanotrophic microorganisms in the sediment, while RNA was used to identify active methanotrophs and the activity of the enzyme methane monooxygenase.

CTD profiles of PAR light and oxygen concentrations (SEA-Bird SBE 911 plus) were collected in the study area from 12 locations during the 2018 sampling campaign between September 19-23. This information was used to infer how light and oxygen availability might have affected methanotrophic bacteria.

Real-time measurement of methane in the surface water. During the 2018 sampling campaign $\mathrm{CH}_{4}$ concentrations at a depth of 0.5-1.0 m of the water column were measured in situ using a Water Equilibration Gas Analyser System (WEGAS), and a full method description and results are presented in Humborg C, Geibel MC, Sun X, McCrackin M, Mörth C-M, Stranne C, Jakobsson M, Gustafsson B, Sokolov A, Norkko A and Norkko J [37]. In brief, circulation pumps equipped to a seawater inlet transfer seawater into an equilibrator with showerhead. The gas is transferred through a gas handling system, and is analysed for $\mathrm{CH}_{4}$ concentrations by a cavity ring-down spectrometer gas analyser (Picarro G2131-i). This system also tracked temperature and salinity as long as Electra was cruising. Even though salinity, temperature, and $\mathrm{CH}_{4}$ for the year 2018 have been measured and is available in Humborg C, Geibel MC, Sun X, McCrackin M, Mörth C-M, Stranne C, Jakobsson M, Gustafsson B, Sokolov A, Norkko A and Norkko $J$ [37], data on the specific stations presented here have not been reported.

Acoustic data of methane seeps from the sediment. Acoustic data were collected during the 2018 sampling September 19-22. The acoustic data were collected with a Simrad EK80 wide band transceiver, transmitting through a hull mounted Simrad ES70-7C split beam transducer with a center frequency of 70 $\mathrm{kHz}$. Position and attitude information were provided to the echo sounder as an integrated solution by a Seapath 330+ GPS/GLONASS navigation and motion reference system. The dataset was match filtered with an ideal replica signal using a MATLAB software package provided by the system manufacturer (Lars Anderson, personal communication, 2014). Seeps were defined as either trains of bubbles or bubble plumes (many bubbles overlapping in vertical structures) and were identified through visual inspection of the processed acoustic data. Ebullition from sediments has been observed in the study area and reported in Humborg C, Geibel MC, Sun X, McCrackin M, Mörth C-M, Stranne C, Jakobsson M, Gustafsson B, Sokolov A, Norkko A and Norkko J [37] but here we present for the first time high resolution acoustic data on: 1) the amount of seeps and 2) the relation of seeps to water depth in the study area. The number of 
seeps per km was derived by applying a running average with a window size of $0.2 \mathrm{~km}$ along the cruise track. For calculations of seeps per $\mathrm{km}$ as a function of depth, the total ship track (about $65 \mathrm{~km}$ ) as well as the number of observed seeps (in total 1975 observations) were divided into $1 \mathrm{~m}$ seafloor depth bins ranging from 5 to $60 \mathrm{~m}$. The number of seeps in each depth bin was then divided by the track length within each depth bin. Note that the tendency of decreasing number of seeps per km with increasing depth becomes significantly stronger if accounting for the footprint of the echo sounder beam (Additional File 1: Fig. S8). This is because the beam footprint increases with depth. While this should provide a more accurate picture in theory, there might be issues with overlapping seeps (multiple seeps being counted as one), and the actual seep distribution might be somewhere in between.

Ammonium analyses. Sediment frozen at $-20^{\circ} \mathrm{C}$ sampled during 2018 was thawed and $20 \mathrm{ml}$ of sediment was transferred into $50 \mathrm{ml}$ centrifuge tubes (Sarstedt). Pore water was extracted by centrifugation at $2200 \times \mathrm{g}$ at $9^{\circ} \mathrm{C}$ followed by filtration of $10 \mathrm{ml}$ supernatant through a $0.45 \mu \mathrm{m}$ polyethersulfone membrane filter (Filtropur S 0.45 , Sarstedt). The pore water was then stored at $-20^{\circ} \mathrm{C}$ until $\mathrm{NH}_{4}{ }^{+}$analyses. Pore water samples were analyzed colorimetrically (Multiskan GO spectrophotometer, Thermo Scientific) for ammonium concentrations and the modified salicylate-hypochlorite method of Bower CE and HolmHansen T [52] was used.

Nucleic acids extraction and sequencing. Ten $\mathrm{g}$ and two $\mathrm{g}$ of sediment were used to extract DNA and RNA using the DNeasy PowerMax Soil kit (QIAGEN) and RNeasy PowerSoil kit (QIAGEN) kits, respectively. DNase treatment was conducted on extracted RNA by using the TURBO DNA-free kit (Invitrogen). This was followed by ribosomal depletion with the RiboMinus Transcriptome Isolation Kit (ThermoFisher Scientific). Library preparation of DNA and RNA samples were prepared with the ThruPLEX DNA-seq (Rubicon Genomics) and TruSeq RNA Library Prep v2 (without the poly-A selection step, Illumina) kits, respectively. The Illumina NovaSeq6000 platform was used to sequence DNA and RNA, with one S2 and S4 lane used for the DNA and RNA samples (a paired-end $2 \times 150$ bp setup), respectively. All samples were sequenced at the Science for Life Laboratory, Stockholm.

Quality trimming of sequences. SeqPrep 1.2 [53] was used to remove Illumina adapters from the sequences. This was followed by removal of any leftover PhiX sequences by mapping the reads against the PhiX genome (NCBI Reference Sequence: NC_001422.1) using bowtie2 2.3.4.3[54]. Trimmomatic 0.36 [55] was used to quality trim reads with the following parameters: LEADING:20 TRAILING:20 MINLEN:50. Final quality of the trimmed reads were checked with FastQC 0.11.5 [56] and MultiQC 1.7 [57]. See Additional File 2: Data S7 for full details of sequence counts before and after quality trimming, average read lengths, extracted 16S rRNA gene sequences etc.

Taxonomic annotation. All metagenomic DNA sequences and SSU rRNA from the DNA and RNA sequence data were taxonomically classified. SSU rRNA data was extracted with SortMeRNA 2.1b [58] followed by annotation using Kraken2 2.0.7 [59]. Kraken2 was run with a paired-end setup against the NCBI RefSeq genome database (database downloaded 1 March 2019) for all metagenome DNA sequences, while SSU rRNA gene data was run against the small-subunit SILVA [60] (for prokaryotic data, 
database downloaded 1 March 2019) and NCBI NT (for better classification of eukaryotic 18S rRNA gene sequences; database downloaded 12 March 2019). To more accurately estimate the relative abundance of the classified prokaryotic taxonomy Bracken 2.5 [61] was used on the Kraken2 reports (run with default parameters on the genus level and a count threshold of 10). The final Kraken2 reports were then combined into a biom-format file using the python package kraken-biom 1.0.1 (with the following setup: --fmt hdf5 -max D -min S). The python package biom-format 2.1.7 [62] was then used to convert the biomtable to a text table. In the taxonomy table chloroplast sequences were removed, and data was normalized as relative abundance (\%) and analyzed in the software Explicet 2.10.5 [63].

Protein classification of functional genes and RNA transcripts. Paired-end DNA and RNA sequences were merged using PEAR 0.9.10 [64], and non-rRNA sequences were extracted using SortMeRNA/2.1b. Protein annotation was conducted by aligning sequences against the NCBI NR database (e-value threshold < 0.001, database downloaded 2 April 2 2019) using Diamond 0.9.10 [65] in conjunction with BLASTX [66]. MEGAN 6.15.2 [67] was used to analyze the taxonomy and protein classification of the output diamond files using default LCA parameters and software supplied databases (taxonomy: prot_acc2taxNov2018X1.abin, and InterPro protein database: acc2interpro-June2018X.abin). To distinguish between $\mathrm{AMO}$ and $\mathrm{pMMO}$ sequences reads classified against the $\mathrm{AMO} / \mathrm{pMMO}$ protein family was extracted from MEGAN. The extracted sequences were classified against the UniProtKB/Swiss-Prot database (2019 July version) using BLASTX 2.7.1+ with an e-value threshold of 0.001. Data was normalized among samples as counts per million sequences (CPM; relative proportion $\times 1000000)$.

In addition to the assembly-free approach of the RNA transcripts, the metagenomic quality trimmed DNA sequences were used to construct a co-assembly with MEGAHIT 1.1.2 with default settings [68]. This yielded an assembly with 33857159 contigs (average contig length: 736). Prodigal 2.63 [69] was used with default settings to predict genes and proteins in the assembly. The predicted genes were classified using BLASTX (e-value threshold < 0.001) against the UniProtKB/Swiss-Prot database, and genes classified to code for $p m o A$ and $p m o B$ were extracted. The $p m o A B$ genes were delimited to read lengths $>500 \mathrm{bp}$, and the final list of genes was manually checked against the UniProtKB/Swiss-Prot database to ensure they code for particulate methane monooxygenase. The $p m o A B$ sequences were used as a reference that the RNA sequence data was mapped against. Bowtie2 2.3.4.3 [54] was used to build a reference, followed by mapping of the RNA sequences to the $p m o A B$ reference. Samtools 1.9 [70] was used to extract the amount of counts mapped (both R1 and R2 pairs required to map), using the following parameters: samtools view $-\mathrm{C}-\mathrm{f} 1-\mathrm{F} 12$. The final count data was normalized for each sample as CPM values based on each respective metagenome library size. A full list of contig details from the metagenome assembly and prodigal predicted $p m o A B$ genes is available in Additional File 2: Data S3.

\section{Quantitative reverse transcription PCR (RT-qPCR)}

For each DNase treated RNA sample a total of $700 \mathrm{ng}$ were reverse transcribed with random primers using the AccuScript High Fidelity 1 st Strand cDNA Synthesis kit (Agilent). The cDNA samples were diluted $\times 10$ and $2 \mu \mathrm{l}$ were used as a template in $5 \mu \mathrm{lPCR}$ reactions. Reactions were prepared with the 
LightCycler 480 SYBR Green I Master kit (Roche) using $300 \mathrm{nM}$ of each primer, and qPCR was then conducted using an Eco Real Time PCR system (Illumina). The 16S rRNA primer pair 515F and 805R [71, 72] were used to amplify $16 \mathrm{~S}$ rRNA genes reverse transcribed to cDNA as an internal normalizer. The RTqPCR conditions were: an initial denaturation $\left(95^{\circ} \mathrm{C}, 10 \mathrm{~min}\right)$ followed by a single step for annealing and extension at $64^{\circ} \mathrm{C}, 30 \mathrm{sec}$. Primers targeting $p m o A$ genes reverse transcribed to $\mathrm{CDNA}$ were designed based on metagenome assembled $p m o A$ genes (Additional File 2: Data S3). Primers were designed using Primer3 at NCBI Primer-Blast server and the primer sequences are listed in Additional File 2: Data S5. Degenerate $p m o A$ primers (Fwd: GAGYGCATCTCAATCAGCTGTACG, Rv: GTCCAGAAATCCCAGTCACCRC) targeting a $130 \mathrm{bp}$ long fragment were used for RT-qPCR with an initial denaturation step $\left(95^{\circ} \mathrm{C}, 10 \mathrm{~min}\right)$ followed by annealing $\left(60^{\circ} \mathrm{C}, 30 \mathrm{sec}\right)$ and extension $\left(72^{\circ} \mathrm{C}, 5 \mathrm{sec}\right.$ ) (additional non-degenerate primers are listed in Additional File 2: Data S5). To confirm that there was no genomic DNA and primer dimer contamination the inclusion of a water template, an RT-minus run, and analyzes of melting dissociations curves combined with gel electrophoresis were included in the analysis. The RT-qPCR pmoA results were normalized against those of $16 \mathrm{~S}$ rRNA using the $2^{-\Delta \Delta C t}$ method by Livak KJ and Schmittgen TD [73].

Statistics. Alpha diversity (Shannon's H) was conducted using the 201816 rRNA gene DNA data (for all taxonomic classifications, as shown in Additional File 2: Data S1) in the software Explicet after subsampling to the lowest sample size (8753 counts) and bootstrap $\times 100$. Non-metric multidimensional scaling (NMDs) based on the Bray-Curtis dissimilarity index of the relative abundance was analyzed in the software past 3.22 [74]. Shapiro-Wilk tests were used to test for normal distribution of the taxonomy data, and SPSS 26 was used to test for differences among stations using non-parametric Kruskal-Wallis tests or One-Way ANOVAs with post hoc Tukey HSD tests for parametric data. Correlations between variables were conducted with Spearman correlations using data from all stations (two-tailed).

Correlation between $\mathrm{CH}_{4} \mathrm{nM}$ and the relative abundance of Methylococcales in the sediment was done by using the same $\mathrm{nM}$ value for $\mathrm{CH}_{4}$ for each replicate sediment core, as $\mathrm{CH}_{4}$ was measured in the water surface. Acoustic data of $\mathrm{CH}_{4}$ seeps was correlated with water depth using Pearson correlation in the software MATLAB 2017a. Differences in metabolic functions (InterPro classifications of RNA transcripts data) were tested with the R package edgeR 3.24.3 [75]. In more detail, the perl script "run_DE_analysis.pl" supplied with Trinity 2.8.2 [76] was used to run the analysis. The script inputs raw read data, and normalize read counts, and analyze differential gene expression using edgeR. Statistic significances were indicated by false discovery rate $(F D R)$ values $<0.05$. To test for differences in DNA sequencing counts of Methylococcales between offshore and inshore stations in 2018, DESeq2 analyses was conducted with the R package DESeq2 1.26 using default settings [77]. DESeq2 does not normalize data proportionally, but uses size factors determined from the median-of-ratios method adjusting for sequencing depth. Counts for Methylococcales 16S rRNA gene sequences, all other 16S rRNA gene sequences, and the total library size of the DNA metagenome data was used as an input, and the difference between inshore and offshore stations was tested. The DESeq2 output was plotted using the ggplot2 package in R [78].

\section{Declarations}


Ethics approval and consent to participate

Not applicable.

Consent for publication

Not applicable.

Availability of data and materials

The raw sequencing data supporting the conclusions of this article is available in the NCBI BioProject repositories, PRJNA541421 (DNA data) and PRJNA541422 (RNA data).

https://www.ncbi.nlm.nih.gov/bioproject/?term=PRJNA541421

https://www.ncbi.nlm.nih.gov/bioproject/?term=PRJNA541422

Competing interest

The authors declare that they have no competing interest.

\section{Funding}

Individual financial support was provided by the Stockholm University's strategic funds for Baltic Sea research to FN.

\section{Author contributions}

EB designed the study, sampled in the field, conducted laboratory work, bioinformatics, data analyses, and drafted the manuscript. XS measured $\mathrm{CH}_{4}$ during field sampling. $\mathrm{CS}$ collected acoustic data during field sampling and analysed acoustic data. MGS conducted RT-qPCR laboratory work and related data analysis. $\mathrm{SB}$ analysed $\mathrm{NH}_{4}{ }^{+}$samples in the laboratory. MG designed and developed the WEGAS system. AN sampled in the field. $\mathrm{CH}$ assisted with measurements of $\mathrm{CH}_{4}$ during field sampling. FJNA designed the study and contributed to drafting the manuscript. All authors gave feedback on the manuscript and gave final approval for publication.

\section{Acknowledgements}

The authors acknowledge support from the National Genomics Infrastructure in Stockholm funded by Science for Life Laboratory, the Knut and Alice Wallenberg Foundation and the Swedish Research Council, and SNIC/Uppsala Multidisciplinary Center for Advanced Computational Science for assistance with massively parallel sequencing and access to the UPPMAX computational infrastructure.

\section{References}


1. Smith SV, Hollibaugh JT: Coastal metabolism and the oceanic organic carbon balance. Reviews of Geophysics 1993, 31:75-89.

2. Weber T, Wiseman NA, Kock A: Global ocean methane emissions dominated by shallow coastal waters. Nature Communications 2019, 10:4584.

3. Stocker TF, Qin D, Plattner G-K, Tignor M, Allen SK, Boschung J, Nauels A, Xia Y, Bex V, Midgley PM: Climate change 2013: The physical science basis. Cambridge University Press Cambridge; 2013.

4. Nisbet E, Manning M, Dlugokencky E, Fisher R, Lowry D, Michel S, Myhre CL, Platt SM, Allen G, Bousquet $P$ : Very strong atmospheric methane growth in the 4 years 2014-2017: Implications for the Paris Agreement. Global Biogeochemical Cycles 2019, 33:318-342.

5. Kirschke S, Bousquet P, Ciais P, Saunois M, Canadell JG, Dlugokencky EJ, Bergamaschi P, Bergmann D, Blake DR, Bruhwiler L, et al: Three decades of global methane sources and sinks. Nature Geoscience 2013, 6:813.

6. Lassey KR: Livestock methane emission: From the individual grazing animal through national inventories to the global methane cycle. Agricultural and Forest Meteorology 2007, 142:120-132.

7. Schimel J: Rice, microbes and methane. Nature 2000, 403:375-377.

8. Neue HU: Fluxes of methane from rice fields and potential for mitigation. Soil Use and Management 1997, 13:258-267.

9. Giles J: Methane quashes green credentials of hydropower. Nature 2006, 444:524-524.

10. Dlugokencky Edward J, Nisbet Euan G, Fisher R, Lowry D: Global atmospheric methane: budget, changes and dangers. Philosophical Transactions of the Royal Society A: Mathematical, Physical and Engineering Sciences 2011, 369:2058-2072.

11. Saunois M, Bousquet P, Poulter B, Peregon A, Ciais P, Canadell JG, Dlugokencky EJ, Etiope G, Bastviken D, Houweling S, et al: The global methane budget 2000-2012. Earth Syst Sci Data 2016, 8:697-751.

12. Borges AV, Champenois W, Gypens N, Delille B, Harlay J: Massive marine methane emissions from near-shore shallow coastal areas. Scientific Reports 2016, 6:27908.

13. Iversen N: Methane Oxidation in Coastal Marine Environments. In Microbiology of Atmospheric Trace Gases; 1996//; Berlin, Heidelberg. Edited by Murrell JC, Kelly DP. Springer Berlin Heidelberg; 1996: 5168.

14. Bange HW: Nitrous oxide and methane in European coastal waters. Estuarine, Coastal and Shelf Science 2006, 70:361-374.

15. Osudar R, Matoušů A, Alawi M, Wagner D, Bussmann I: Environmental factors affecting methane distribution and bacterial methane oxidation in the German Bight (North Sea). Estuarine, Coastal and Shelf Science 2015, 160:10-21.

16. Bridgham SD, Cadillo-Quiroz H, Keller JK, Zhuang Q: Methane emissions from wetlands: biogeochemical, microbial, and modeling perspectives from local to global scales. Global Change Biology 2013, 19:1325-1346. 
17. Enzmann F, Mayer F, Rother M, Holtmann D: Methanogens: biochemical background and biotechnological applications. AMB Express 2018, 8:1-1.

18. Knittel K, Boetius A: Anaerobic oxidation of methane: progress with an unknown process. Annual Review of Microbiology 2009, 63:311-334.

19. Ettwig KF, Butler MK, Le Paslier D, Pelletier E, Mangenot S, Kuypers MMM, Schreiber F, Dutilh BE, Zedelius J, de Beer D, et al: Nitrite-driven anaerobic methane oxidation by oxygenic bacteria. Nature 2010, 464:543.

20. Bowman JP: Methylococcales. In Bergey's Manual of Systematics of Archaea and Bacteria. Edited by Whitman WB, Rainey F, Kämpfer P, Trujillo M, Chun J, DeVos P, Hedlund B, Dedysh S; 2016

21. Kalyuzhnaya MG, Gomez OA, Murrell JC: The Methane-Oxidizing Bacteria (Methanotrophs). In Taxonomy, Genomics and Ecophysiology of Hydrocarbon-Degrading Microbes. Edited by McGenity TJ. Cham: Springer International Publishing; 2019: 1-34

22. Bornemann M, Bussmann I, Tichy L, Deutzmann J, Schink B, Pester M: Methane release from sediment seeps to the atmosphere is counteracted by highly active Methylococcaceae in the water column of deep oligotrophic Lake Constance. FEMS Microbiology Ecology 2016, 92.

23. Smith GJ, Angle JC, Solden LM, Borton MA, Morin TH, Daly RA, Johnston MD, Stefanik KC, Wolfe R, Gil B, Wrighton KC: Members of the genus Methylobacter are inferred to account for the majority of aerobic methane oxidation in oxicsoils from a freshwater wetland. mBio 2018, 9:e00815-00818.

24. Taubert M, Grob C, Crombie A, Howat AM, Burns OJ, Weber M, Lott C, Kaster A-K, Vollmers J, Jehmlich N, et al: Communal metabolism by Methylococcaceae and Methylophilaceae is driving rapid aerobic methane oxidation in sediments of a shallow seep near Elba, Italy. Environmental Microbiology, 0.

25. Heyer J, Berger U: Methane Emission from the Coastal Area in the Southern Baltic Sea. Estuarine, Coastal and Shelf Science 2000, 51:13-30.

26. Bastviken D: Methane. In Encyclopedia of Inland Waters. Edited by Likens GE. Oxford: Academic Press; 2009: 783-805

27. King GM, Blackburn TH: Controls of methane oxidation in sediments. SIL Communications, 195319961996, 25:25-38.

28. Knief C: Diversity and Habitat Preferences of Cultivated and Uncultivated Aerobic Methanotrophic Bacteria Evaluated Based on pmoA as Molecular Marker. Frontiers in Microbiology 2015, 6.

29. Ho A, De Roy K, Thas O, De Neve J, Hoefman S, Vandamme P, Heylen K, Boon N: The more, the merrier: heterotroph richness stimulates methanotrophic activity. The ISME journal 2014, 8:1945.

30. Veraart AJ, Garbeva P, van Beersum F, Ho A, Hordijk CA, Meima-Franke M, Zweers AJ, Bodelier PLE: Living apart together-bacterial volatiles influence methanotrophic growth and activity. The ISME journal 2018, 12:1163-1166.

31. Bodelier PLE, Frenzel P: Contribution of Methanotrophic and Nitrifying Bacteria to $\mathrm{CH}_{4}$ and $\mathrm{NH}_{4}{ }^{+}$ Oxidation in the Rhizosphere of Rice Plants as Determined by New Methods of Discrimination. 
Applied and Environmental Microbiology 1999, 65:1826-1833.

32. Bédard $\mathrm{C}$, Knowles R: Physiology, biochemistry, and specific inhibitors of $\mathrm{CH}_{4}, \mathrm{NH}_{4}{ }^{+}$, and $\mathrm{CO}$ oxidation by methanotrophs and nitrifiers. Microbiology and Molecular Biology Reviews 1989, 53:6884.

33. He R, Chen M, Ma R-C, Su Y, Zhang X: Ammonium conversion and its feedback effect on methane oxidation of Methylosinus sporium. Journal of Bioscience and Bioengineering 2017, 123:466-473.

34. Dumestre JF, Guézennec J, Galy-Lacaux C, Delmas R, Richard S, Labroue L: Influence of Light Intensity on Methanotrophic Bacterial Activity in Petit Saut Reservoir, French Guiana. Applied and Environmental Microbiology 1999, 65:534.

35. Murase J, Sugimoto A: Inhibitory effect of light on methane oxidation in the pelagic water column of a mesotrophic lake (Lake Biwa, Japan). Limnology and oceanography 2005, 50:1339-1343.

36. Savvichev AS, Kadnikov VV, Kallistova AY, Rusanov II, Voronov DA, Krasnova ED, Ravin NV, Pimenov NV: Light-Dependent Methane Oxidation Is the Major Process of the Methane Cycle in the Water Column of the Bol'shie Khruslomeny Polar Lake. Microbiology 2019, 88:370-374.

37. Humborg C, Geibel MC, Sun X, McCrackin M, Mörth C-M, Stranne C, Jakobsson M, Gustafsson B, Sokolov A, Norkko A, Norkko J: High Emissions of Carbon Dioxide and Methane From the Coastal Baltic Sea at the End of a Summer Heat Wave. Frontiers in Marine Science 2019, 6:1-14.

38. Tavormina PL: Methyloprofundus. Bergey's Manual of Systematics of Archaea and Bacteria 2015:17.

39. Osudar R, Klings K-W, Wagner D, Bussmann I: Effect of salinity on microbial methane oxidation in freshwater and marine environments. Aquatic Microbial Ecology 2017, 80:181-192.

40. Bonaglia S, Hylén A, Rattray JE, Kononets MY, Ekeroth N, Roos P, Thamdrup B, Brüchert V, Hall POJ: The fate of fixed nitrogen in marine sediments with low organic loading: an in situ study. Biogeosciences 2017, 14:285-300.

41. You J, Das A, Dolan EM, Hu Z: Ammonia-oxidizing archaea involved in nitrogen removal. Water Research 2009, 43:1801-1809.

42. Vilbaste S, SundbÄCk K, Nilsson C, Truu J: Distribution of benthic diatoms in the littoral zone of the Gulf of Riga, the Baltic Sea. European Journal of Phycology 2000, 35:373-385.

43. Garcia SL, Szekely AJ, Bergvall C, Schattenhofer M, Peura S: Decreased Snow Cover Stimulates Under-Ice Primary Producers but Impairs Methanotrophic Capacity. mSphere 2019, 4:e00626-00618.

44. Guerrero MA, Jones RD: Photoinhibition of marine nitrifying bacteria. I. Wavelength-dependent response. Marine Ecology Progress Series 1996, 141:183-192.

45. Holmes AJ, Costello A, Lidstrom ME, Murrell JC: Evidence that participate methane monooxygenase and ammonia monooxygenase may be evolutionarily related. FEMS microbiology letters 1995, 132:203-208.

46. King GM, Roslev P, Skovgaard H: Distribution and rate of methane oxidation in sediments of the Florida everglades. Applied and environmental microbiology 1990, 56:2902-2911. 
47. Bastviken D, Tranvik LJ, Downing JA, Crill PM, Enrich-Prast A: Freshwater methane emissions offset the continental carbon sink. Science 2011, 331:50-50.

48. Matveev A, Laurion I, Deshpande BN, Bhiry N, Vincent WF: High methane emissions from thermokarst lakes in subarctic peatlands. Limnology and Oceanography 2016, 61:S150-S164.

49. Thornton BF, Geibel MC, Crill PM, Humborg C, Mörth C-M: Methane fluxes from the sea to the atmosphere across the Siberian shelf seas. Geophysical Research Letters 2016, 43:5869-5877.

50. Shakhova N, Semiletov I, Leifer I, Sergienko V, Salyuk A, Kosmach D, Chernykh D, Stubbs C, Nicolsky D, Tumskoy V, Gustafsson Ö: Ebullition and storm-induced methane release from the East Siberian Arctic Shelf. Nature Geoscience 2013, 7:64.

51. Deemer BR, Harrison JA, Li S, Beaulieu JJ, DelSontro T, Barros N, Bezerra-Neto JF, Powers SM, dos Santos MA, Vonk JA: Greenhouse Gas Emissions from Reservoir Water Surfaces: A New Global Synthesis. BioScience 2016, 66:949-964.

52. Bower CE, Holm-Hansen T: A Salicylate-Hypochlorite Method for Determining Ammonia in Seawater. Canadian Journal of Fisheries and Aquatic Sciences 1980, 37:794-798.

53. St John J: SeqPrep. 2014.

54. Langmead B, Salzberg SL: Fast gapped-read alignment with Bowtie 2. Nature Methods 2012, 9:357.

55. Bolger AM, Lohse M, Usadel B: Trimmomatic: A flexible trimmer for lllumina sequence data. Bioinformatics 2014, 30:2114-2120.

56. Andrews S: FastQC: a quality control tool for high throughput sequence data. 2010.

57. Ewels P, Magnusson M, Käller M, Lundin S: MultiQC: summarize analysis results for multiple tools and samples in a single report. Bioinformatics 2016, 32:3047-3048.

58. Kopylova E, Noé L, Touzet H: SortMeRNA: fast and accurate filtering of ribosomal RNAs in metatranscriptomic data. Bioinformatics 2012, 28:3211-3217.

59. Wood DE, Lu J, Langmead B: Improved metagenomic analysis with Kraken 2. Genome Biology 2019, 20:257.

60. Quast C, Pruesse E, Yilmaz P, Gerken J, Schweer T, Yarza P, Peplies J, Glöckner FO: The SILVA ribosomal RNA gene database project: improved data processing and web-based tools. Nucleic Acids Research 2013, 41:D590-D596.

61. Lu J, Breitwieser FP, Thielen P, Salzberg SL: Bracken: estimating species abundance in metagenomics data. PeerJ Computer Science 2017, 3:e104.

62. McDonald D, Clemente JC, Kuczynski J, Rideout JR, Stombaugh J, Wendel D, Wilke A, Huse S, Hufnagle J, Meyer F: The Biological Observation Matrix (BIOM) format or: how I learned to stop worrying and love the ome-ome. GigaScience 2012, 1:7.

63. Robertson CE, Harris JK, Wagner BD, Granger D, Browne K, Tatem B, Feazel LM, Park K, Pace NR, Frank DN: Explicet: graphical user interface software for metadata-driven management, analysis and visualization of microbiome data. Bioinformatics 2013, 29:3100-3101. 
64. Zhang J, Kobert K, Flouri T, Stamatakis A: PEAR: a fast and accurate Illumina Paired-End reAd mergeR. Bioinformatics 2014, 30:614-620.

65. Buchfink B, Xie C, Huson DH: Fast and sensitive protein alignment using DIAMOND. Nature Methods 2015, 12:59-60.

66. Altschul SF, Gish W, Miller W, Myers EW, Lipman DJ: Basic local alignment search tool. Journal of Molecular Biology 1990, 215:403-410.

67. Huson DH, Mitra S: Introduction to the analysis of environmental sequences: metagenomics with MEGAN. Methods in Molecular Biology 2012, 856:415-429.

68. Li D, Luo R, Liu CM, Leung CM, Ting HF, Sadakane K, Yamashita H, Lam TW: MEGAHIT v1.0: A fast and scalable metagenome assembler driven by advanced methodologies and community practices. Methods 2016, 102:3-11.

69. Hyatt D, Chen GL, Locascio PF, Land ML, Larimer FW, Hauser LJ: Prodigal: prokaryotic gene recognition and translation initiation site identification. BMC Bioinformatics 2010, 11:119.

70. Li H, Handsaker B, Wysoker A, Fennell T, Ruan J, Homer N, Marth G, Abecasis G, Durbin R: The sequence alignment/map format and SAMtools. Bioinformatics 2009, 25:2078-2079.

71. Parada AE, Needham DM, Fuhrman JA: Every base matters: assessing small subunit rRNA primers for marine microbiomes with mock communities, time series and global field samples. Environmental microbiology 2016, 18:1403-1414.

72. Herlemann DP, Labrenz M, Jurgens K, Bertilsson S, Waniek JJ, Andersson AF: Transitions in bacterial communities along the 2000 km salinity gradient of the Baltic Sea. The ISME Journal 2011, 5:15711579 .

73. Livak KJ, Schmittgen TD: Analysis of relative gene expression data using real-time quantitative PCR and the $2^{-\triangle \Delta C T}$ method. methods 2001, 25:402-408.

74. Hammer $\varnothing$, Harper DAT, Ryan PD: PAST: Paleontological statistics software package for education and data analysis. Palaeontologia Electronica 2001, 4:9.

75. Robinson MD, McCarthy DJ, Smyth GK: edgeR: a Bioconductor package for differential expression analysis of digital gene expression data. Bioinformatics 2010, 26:139-140.

76. Haas BJ, Papanicolaou A, Yassour M, Grabherr M, Blood PD, Bowden J, Couger MB, Eccles D, Li B, Lieber $\mathrm{M}$, et al: De novo transcript sequence reconstruction from RNA-seq using the Trinity platform for reference generation and analysis. Nature Protocols 2013, 8:1494-1512.

77. Love MI, Huber W, Anders S: Moderated estimation of fold change and dispersion for RNA-seq data with DESeq2. Genome Biology 2014, 15:550.

78. Wickham H: ggplot2: elegant graphics for data analysis. Springer; 2016.

\section{Tables}


Table 1 List of the station numbers ("off" denotes offshore stations (5, 7, 10, 13), and inshore stations are denoted solely by their station number 11,

$12,15,16)$, the amount of sediment cores collected and sliced (0-2 $\mathrm{cm}$ surface) for DNA/RNA extraction or pore water $\mathrm{NH}_{4}{ }^{+}$analyses, sampling dates during 2017 and 2018, latitude, longitude, and water column depth.

\begin{tabular}{c|ccccccc}
\hline Station & DNA/RNA extraction $(n)$ & $\mathrm{NH}_{4}{ }^{+}$analyses $(n)$ & 2017 date & 2018 date & Lat. (dd) & Long. (dd) & Depth $(\mathrm{m})$ \\
\hline $\begin{array}{c}\text { off-5 } \\
\text { off-7 }\end{array}$ & 3 & - & Jun 4 & - & 59.8319 & 23.29566 & 45 \\
off-10 & 3 & 3 & Jun 4 & Sep 23 & 59.8430 & 23.28035 & 37 \\
11 & 3 & 3 & Jun 4 & Sep 20 & 59.8559 & 23.26695 & 36 \\
12 & 3 & 3 & Jun 4 & Sep 20 & 59.8521 & 23.25475 & 18 \\
off-13 & 3 & 3 & Jun 4 & Sep 22 & 59.8521 & 23.24495 & 10 \\
15 & 3 & 3 & Jun 4 & Sep 22 & 59.8620 & 23.25615 & 40 \\
16 & 3 & 3 & Jun 5 & Sep 20 & 59.8602 & 23.25155 & 28 \\
\hline
\end{tabular}

Table $2 \mathrm{CH}_{4}$ measured in the 0-0.5 m surface water (nM), pore water $\mathrm{NH}_{4}{ }^{+}$concentrations ( $\left.\mu \mathrm{M}\right)$, RNA transcripts attributed to proteins affiliated with the Photosynthesis GO category, whole microbial community AMO/pMMO proteins (CPM values), mapped RNA transcripts against metagenome assembled pmoAB genes (CPM), and RT-qPCR relative levels of pmoA transcript numbers (NRQ, normalized for 16S rRNA). Offshore stations are denoted with the label "off", and dashes in the table denote no data collected. 


\begin{tabular}{|c|c|c|c|c|c|c|c|c|}
\hline \multirow[b]{2}{*}{ Station } & \multirow{2}{*}{$\begin{array}{r}\mathrm{CH}_{4} \\
2018\end{array}$} & \multirow{2}{*}{$\begin{array}{c}\mathrm{NH}_{4}{ }^{+} \\
2018\end{array}$} & \multirow{2}{*}{$\begin{array}{c}\text { Photosynthesis } \\
2018 \\
\text { RNA }\end{array}$} & \multicolumn{3}{|c|}{ InterPro AMO/pMMO } & \multirow{2}{*}{$\begin{array}{c}\text { Mapped pmoABtranscripts } \\
2018 \\
\text { RNA }\end{array}$} & \multirow{2}{*}{$\begin{array}{c}\text { RT-qPCR pmoA } \\
2018 \\
\text { RNA }\end{array}$} \\
\hline & & & & 2018 RNA & 2018 DNA & 2017 DNA & & \\
\hline off-5 A & - & & - & - & - & 1552 & - & - \\
\hline off-5 B & & - & - & - & - & 1536 & - & - \\
\hline off-5 C & & & - & - & - & 1539 & - & - \\
\hline off-7 A & 16.2 & 336 & 8402 & 6763 & 1455 & 1494 & 143 & 0.0020 \\
\hline off-7 B & & 417 & 7254 & 7250 & 1450 & 1485 & 195 & 0.0020 \\
\hline off-7 C & & 385 & 8131 & 9018 & 1445 & 1479 & 175 & 0.0023 \\
\hline off-10 A & 15.8 & 297 & 5210 & 12738 & 1460 & 1495 & 337 & 0.0037 \\
\hline off-10 B & & 267 & 5190 & 11562 & 1528 & 1499 & 394 & 0.0033 \\
\hline off-10 C & & 251 & 3838 & 11117 & 1486 & 1482 & 249 & 0.0028 \\
\hline $11 \mathrm{~A}$ & 40.6 & 193 & 9187 & 1842 & 1519 & 1477 & 2 & 0 \\
\hline $11 \mathrm{~B}$ & & 199 & 8137 & 2156 & 1523 & 1429 & 5 & 0 \\
\hline $11 \mathrm{C}$ & & 147 & 6128 & 2241 & 1500 & 1454 & 6 & 0 \\
\hline $12 \mathrm{~A}$ & 29.8 & 194 & 16818 & 1635 & 1458 & 1460 & 3 & 0 \\
\hline $12 \mathrm{~B}$ & & 161 & 15792 & 1804 & 1457 & 1441 & 3 & 0 \\
\hline $12 \mathrm{C}$ & & 170 & 13684 & 2010 & 1502 & 1456 & 3 & 0 \\
\hline off-13 A & 23.4 & 276 & 5247 & 12530 & 1652 & 1459 & 503 & 0.0048 \\
\hline off-13 B & & 253 & 5222 & 12990 & 1605 & 1488 & 491 & 0.0047 \\
\hline off-13 C & & 286 & 6100 & 10165 & 1634 & 1504 & 290 & 0.0038 \\
\hline $15 \mathrm{~A}$ & 23.4 & 281 & 5244 & 2709 & 1510 & 1533 & 13 & 0.0001 \\
\hline $15 \mathrm{~B}$ & & 283 & 4376 & 3285 & 1497 & 1503 & 22 & 0.0003 \\
\hline $15 \mathrm{C}$ & & 254 & 5699 & 2577 & 1478 & 1548 & 15 & 0.0001 \\
\hline $16 \mathrm{~A}$ & 23.6 & 152 & 21523 & 1855 & 1491 & 1477 & 1 & 0 \\
\hline $16 \mathrm{~B}$ & & 156 & 24214 & 1606 & 1494 & 1500 & 0 & 0 \\
\hline $16 \mathrm{C}$ & & 167 & 11963 & 1674 & 1482 & 1453 & 0 & 0 \\
\hline
\end{tabular}

Figures 

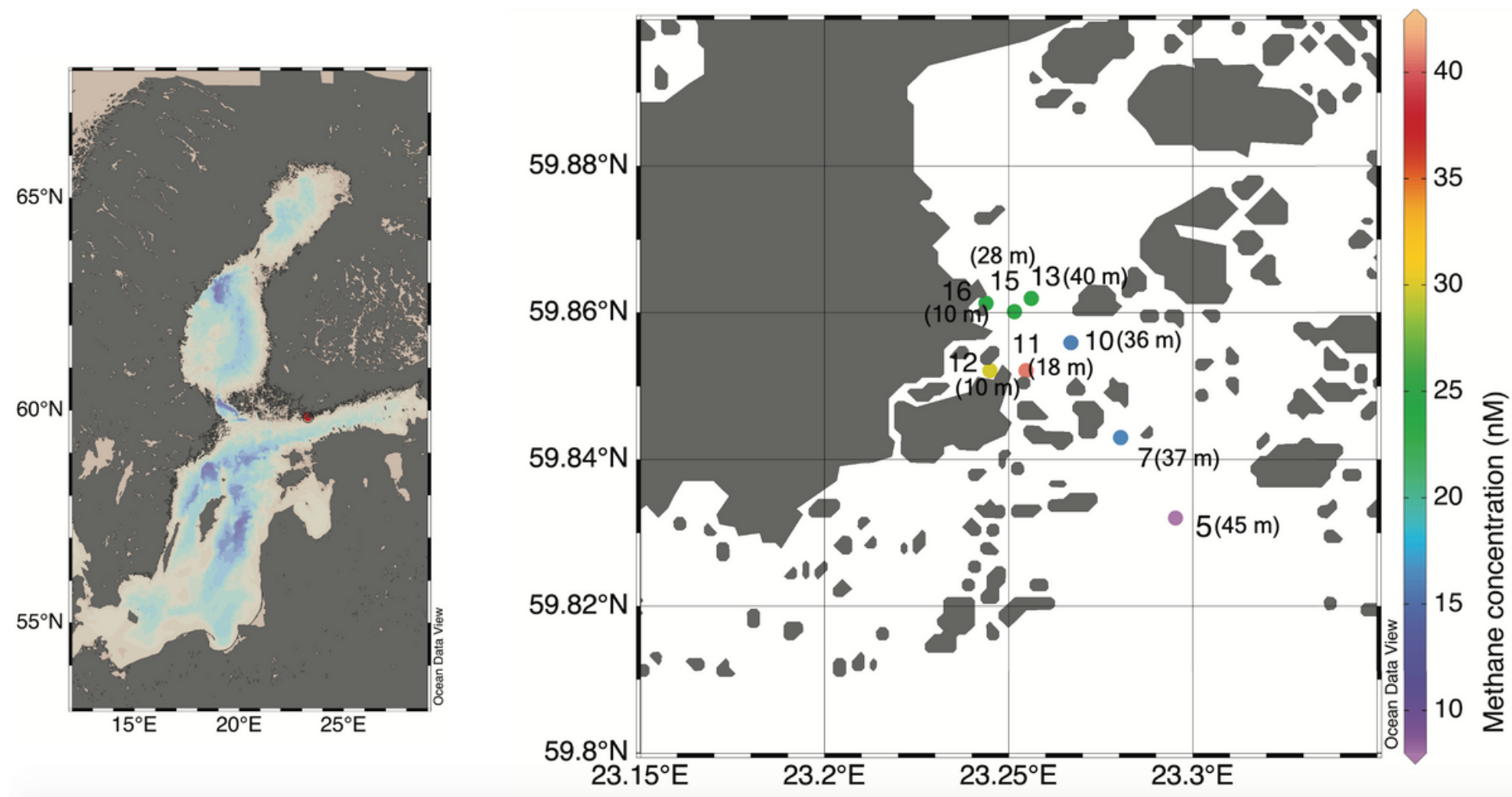

Figure 1

The map shows the Baltic Sea and the location of the study area in the Western Gulf of Finland.

Sediment was collected (top 0-2 cm surface) during June 2017 and September 2018 from the eight sampling stations in the Storfjärden bay $(n=3$ per station). The colour legend shows the methane concentration in the surface water for each station $(0-0.5 \mathrm{~m})$, while the parenthesis between each station number shows the water column depth $(\mathrm{m})$. 


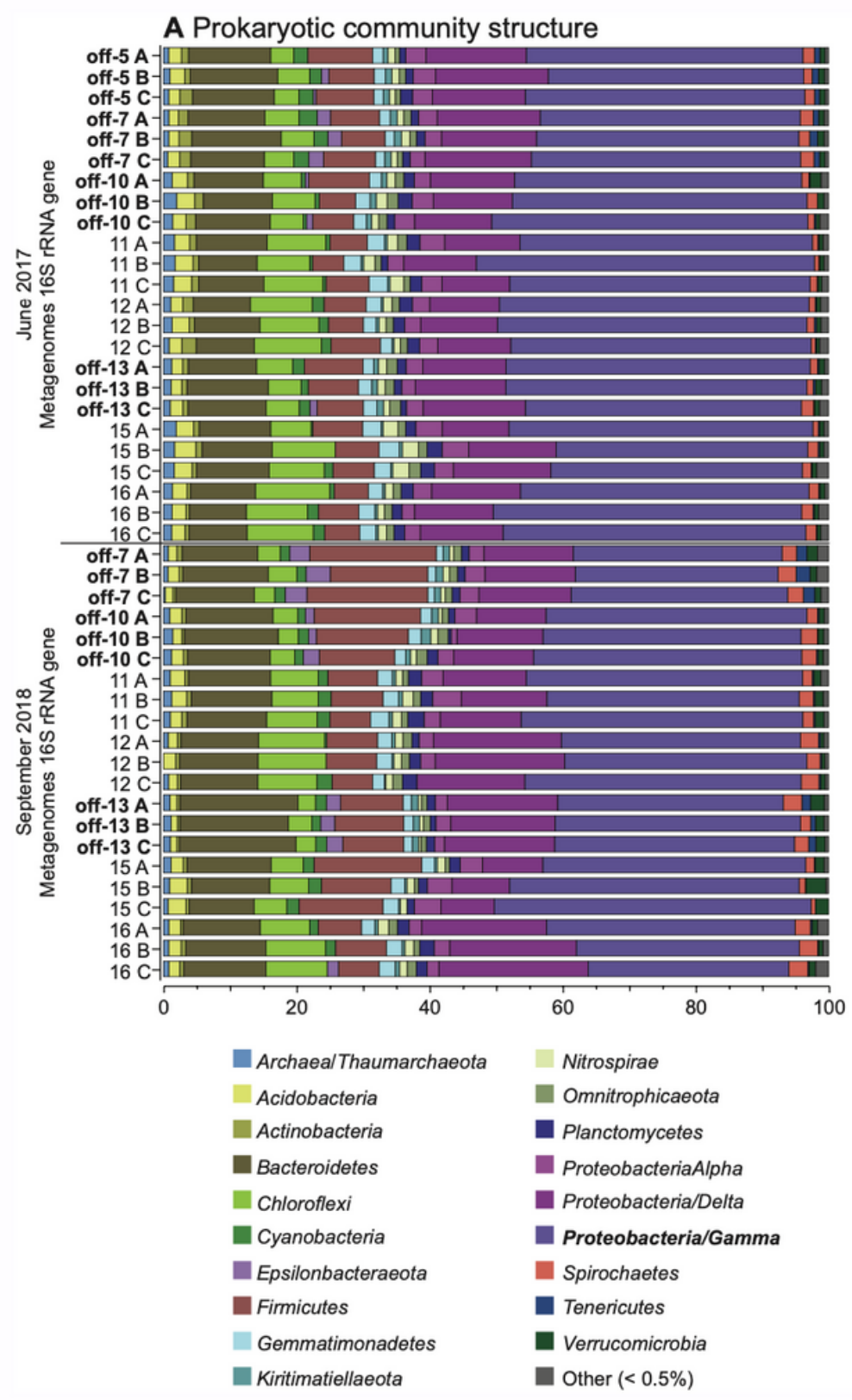

\section{B Gammaproteobacteria}

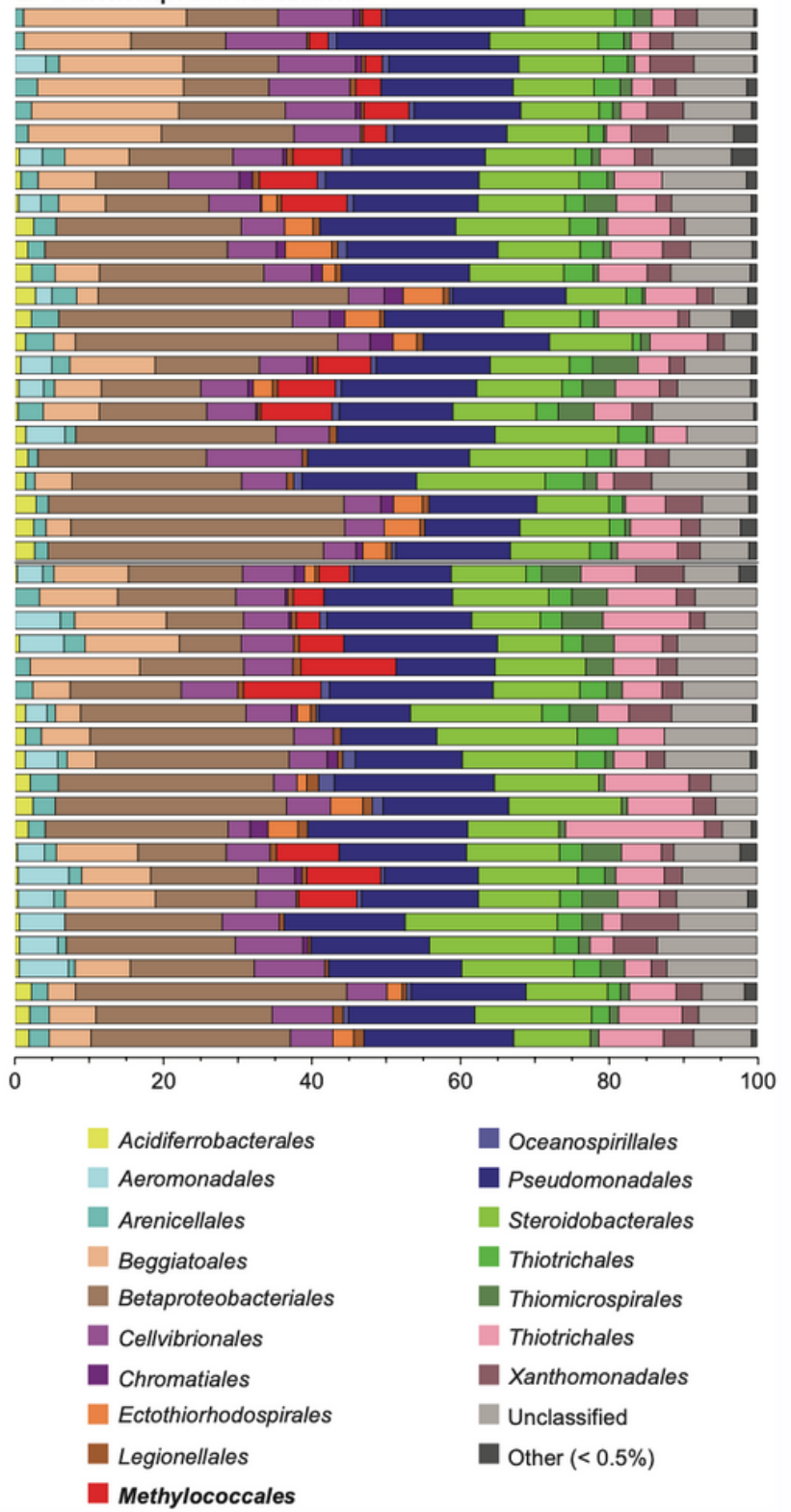

Figure 2

The stacked bars show relative abundance (x-axis \%) of A) prokaryotic phyla and Proteobacteria classes, and B) Gammaproteobacteria orders. The dataset was delimited to taxonomic groups $>0.5 \%$ (average of all samples), and bold text denote Gammaproteobacteria (in A) and methanotrophic Gammaproteobacteria (in B). The y-axis shows the sampling year, and station names and replicate samples indicated by letters A, B, and C. Offshore stations are indicated on the y-axis with the label "off". 


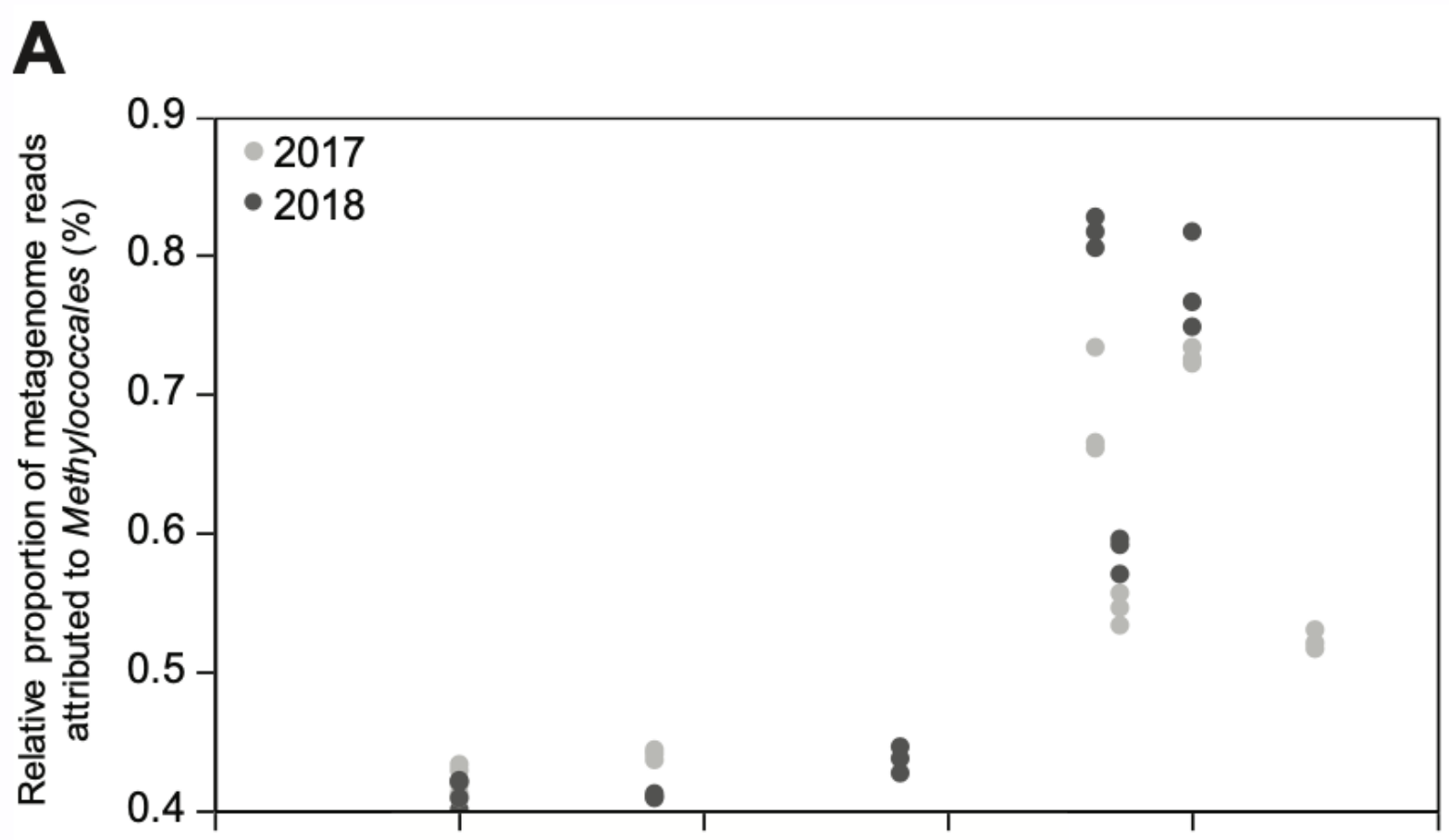

B

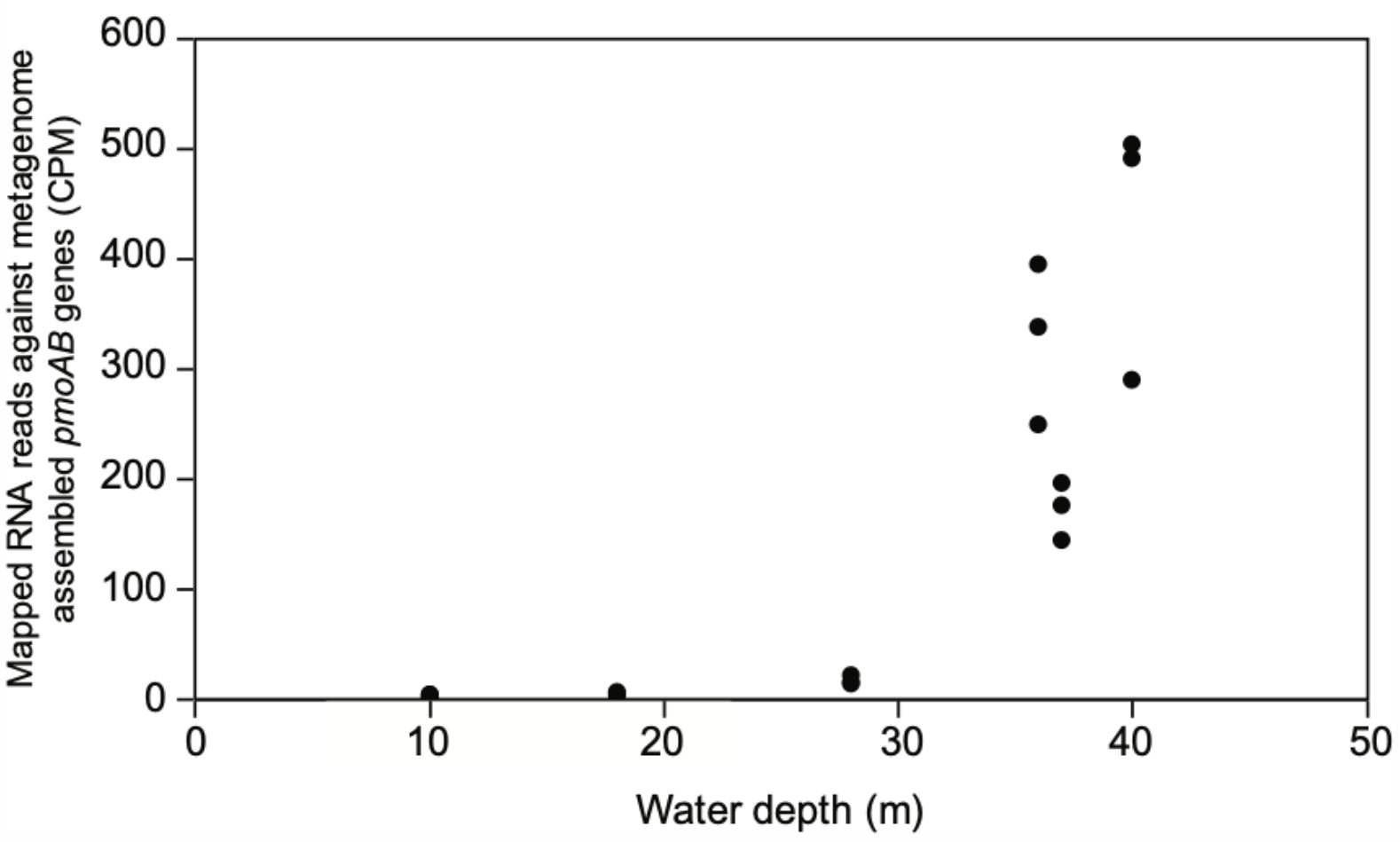

Figure 3

A) The relative proportion of reads (y-axis \%) attributed to the methanotrophic Gammaproteobacteria order Methylococcales compared to the whole prokaryotic community. The data was based on all metagenomic sequences classified against the NCBI RefSeq genome database. The x-axis shows the water depth $(\mathrm{m})$, each circle represents one sediment core, and the colours denotes the sampling year (light grey as 2017, and dark grey as 2018). The water depth for the stations are: $10 \mathrm{~m}$ (stations 12 and 
16), $18 \mathrm{~m}$ (11), $28 \mathrm{~m}$ (15), $36 \mathrm{~m}$ (10), $37 \mathrm{~m}$ (7), $40 \mathrm{~m}$ (13), and $45 \mathrm{~m}$ (5). B) Mapped RNA reads (2018 RNA data) against metagenome assembled pmoAB genes (> 500 bp long, 2018 DNA data). The data shows normalized sequence counts (counts per million sequences; CPM values). The $x$-axis shows the water depth $(m)$, and each circle represents one sediment core.
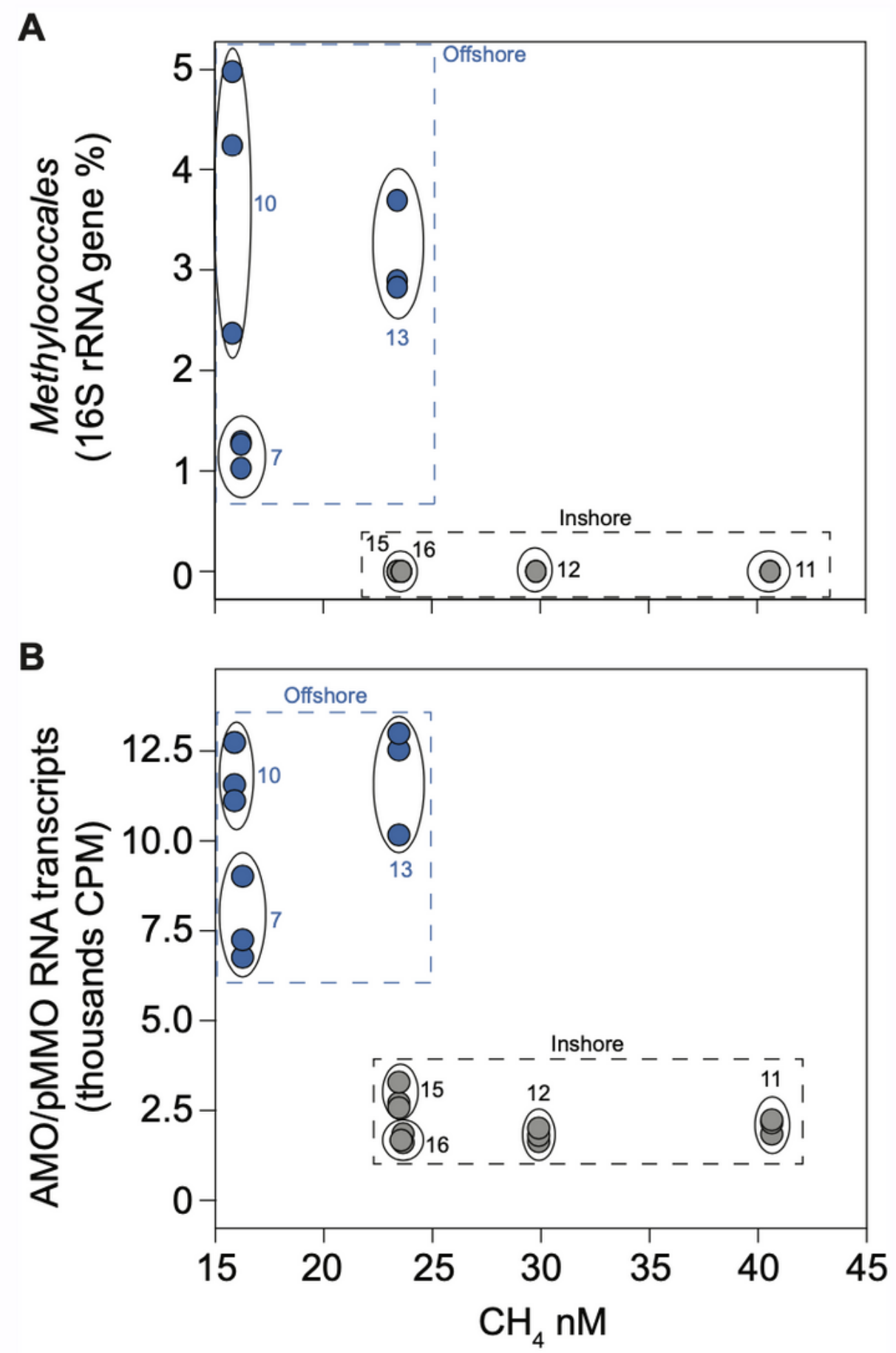

Figure 4 
A) The relative abundance of the methanotrophic Gammaproteobacteria order Methylococcales in the 0$2 \mathrm{~cm}$ sediment surface ( $\mathrm{y}$-axis, $\mathrm{n}=3$ per station) and measured $\mathrm{CH} 4$ in the water column ( $\mathrm{x}$-axis, $\mathrm{n}=1$ per station). The relative abundance of Methylococcales shown is based 16S rRNA gene sequences extracted from the 2018 DNA data, while $\mathrm{CH} 4$ was measured in the water surface (0.5-1.0 m water depth). B) RNA transcripts of the whole prokaryotic community classified as $\mathrm{AMO} / \mathrm{pMMO}$ against the InterPro database (based on classifying all paired-end merged RNA reads against NCBI NR and linking accession numbers to the InterPro database). Values shown are normalized sequence counts (CPM). Red filled circles denote stations further away from the coast, and the outlining circles show the sampling stations for each cluster of data points.

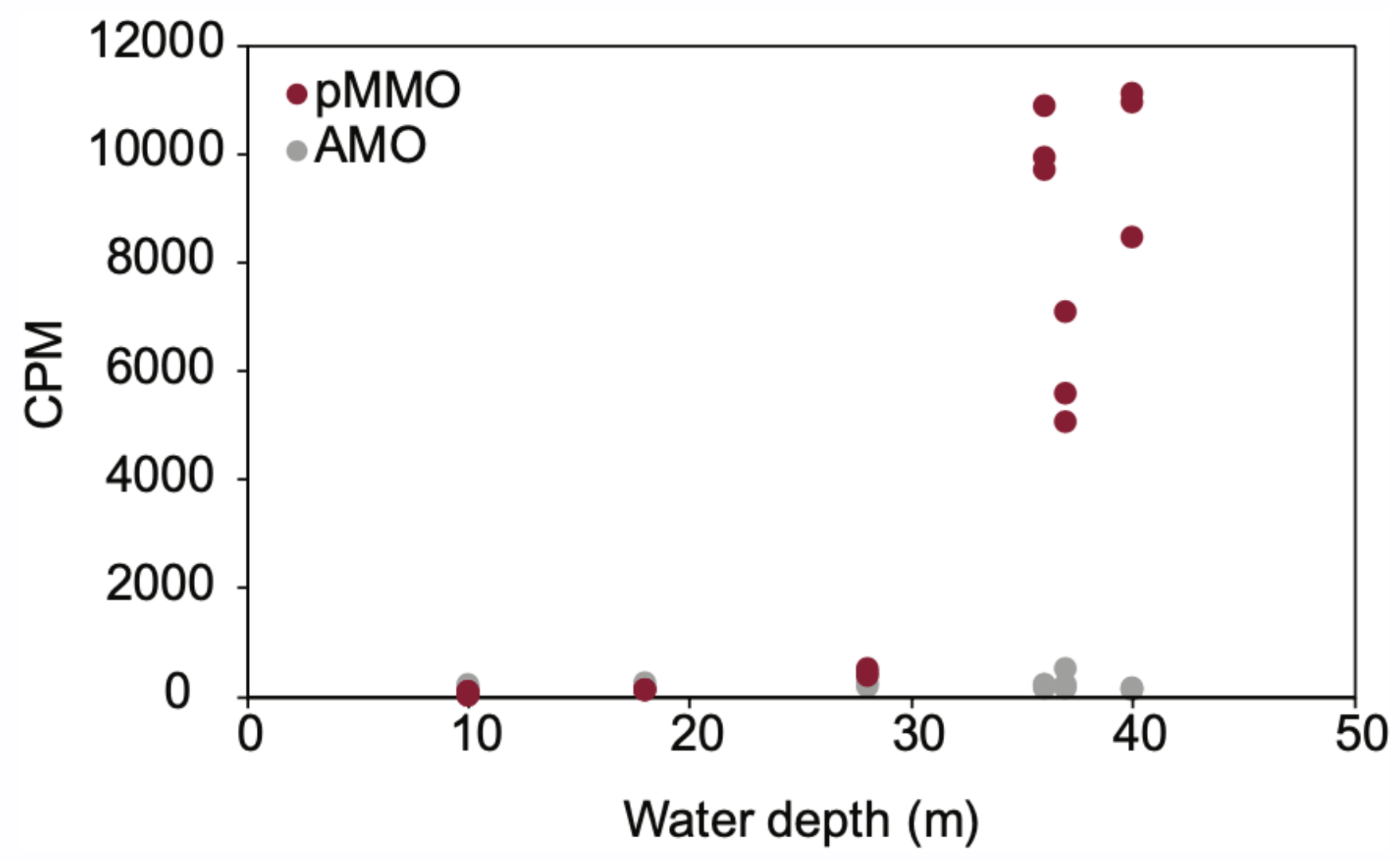

Figure 5

RNA sequences annotated to the InterPro AMO/pMMO family was classified against the UniProtKB/Swiss-Prot database and compared to the water depth $(m)$ of the stations (x-axis). CPM values shown are based on all proteins classified against the InterPro database ( $y$-axis). Each circle in the graph denotes RNA transcripts derived from the 0-2 sediment surface from individual sediment cores. Dark red circles denote PMMO and light grey circles denote AMO. 


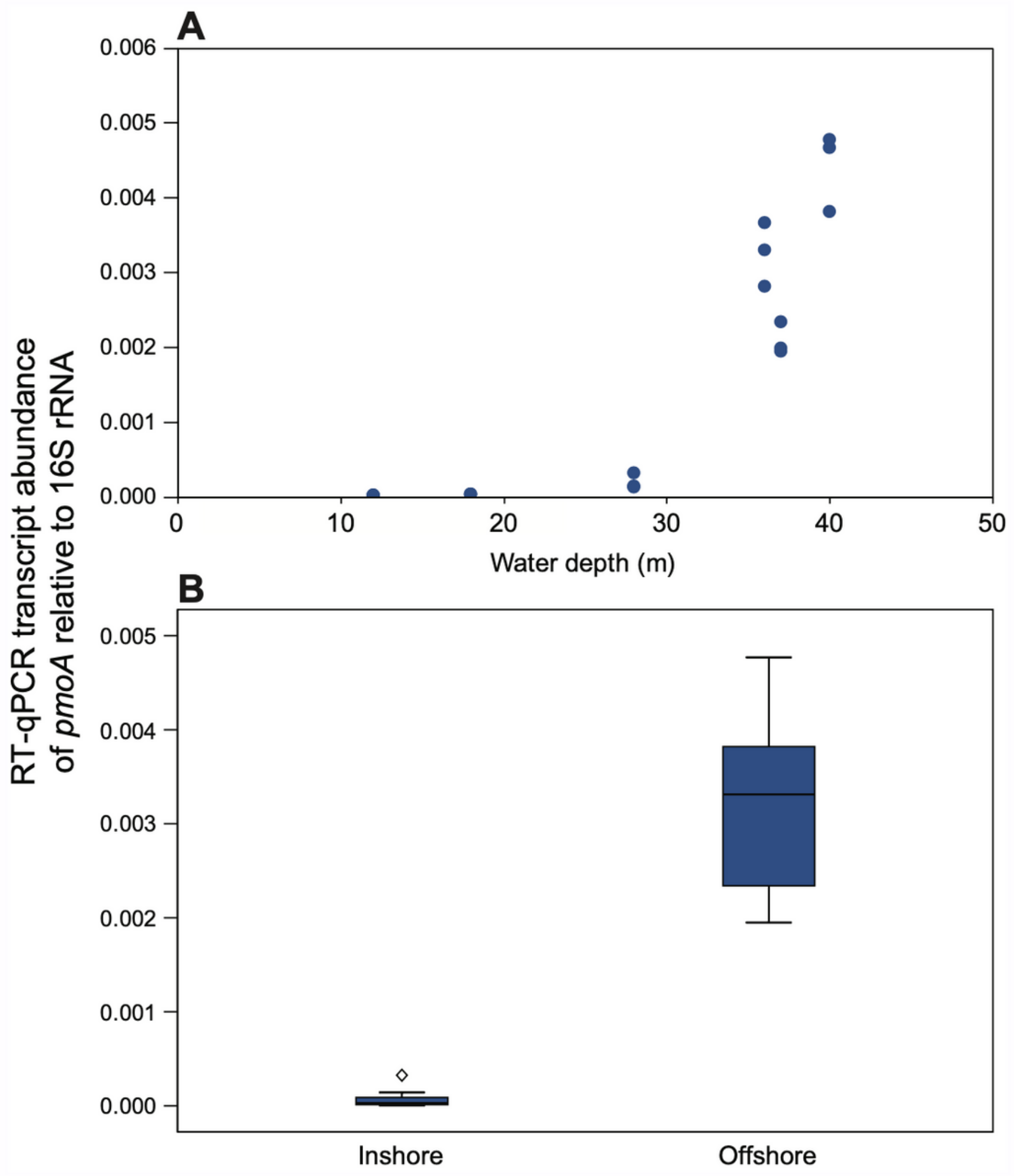

Figure 6

A) RT-qPCR results showing the number of pmoA RNA transcripts relative to 16S rRNA for each station along the water depth gradient (y-axis shows NRQ; normalized relative quantification). B) Boxplot graph showing the inshore stations compared to the offshore stations. The diamond symbol denotes an outlier 3 or more box lengths from the median. 

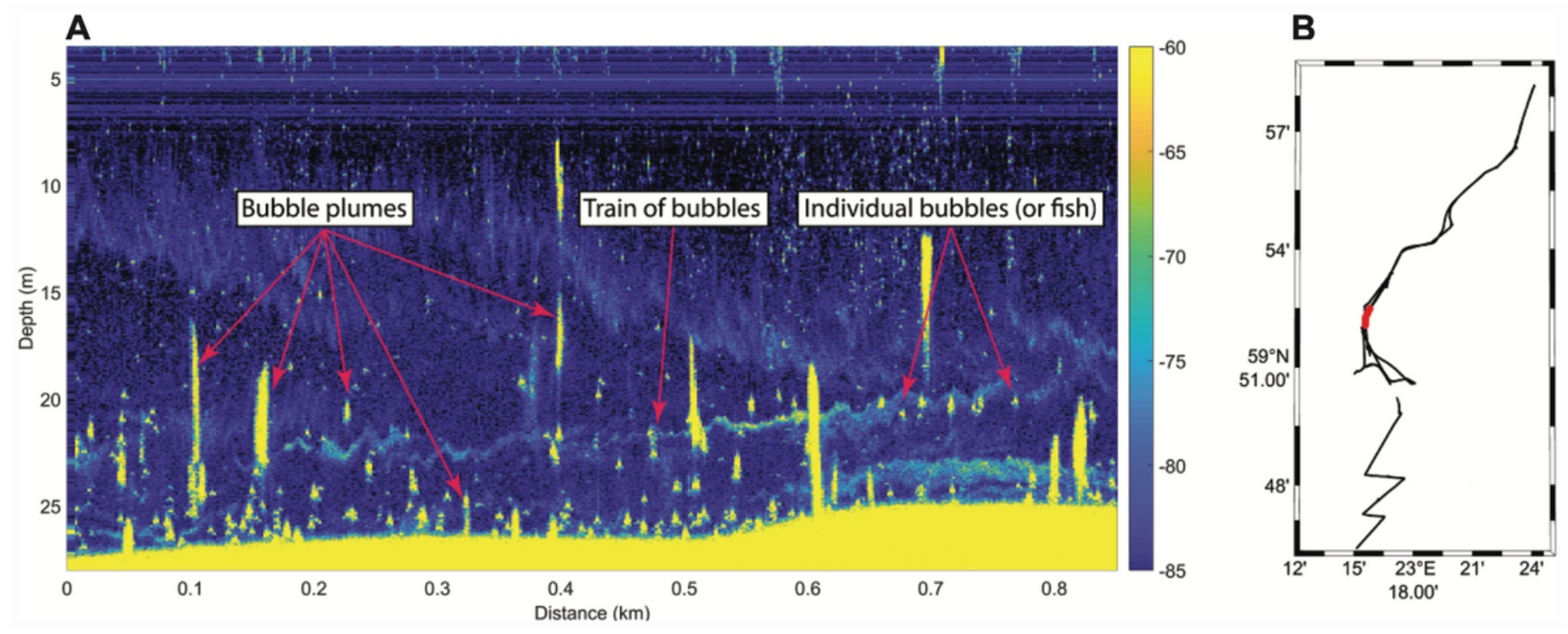

Figure 7

Onboard the research vessel acoustic data (EK80 wide band transceiver) was collected from the southern, central, and northern Storfjärden bay. A) Example of echogram with seeps from the seafloor and within the water column. The right-side $y$-axis shows target strength $(\mathrm{dB})$ as a function of horizontal distance ( $x$ axis) and water depth (left-side y-axis). B) Map of the Storfjärden bay showing the data track from all the acoustic data that were collected (black) and the track shown in the echogram in $A$ (red). 

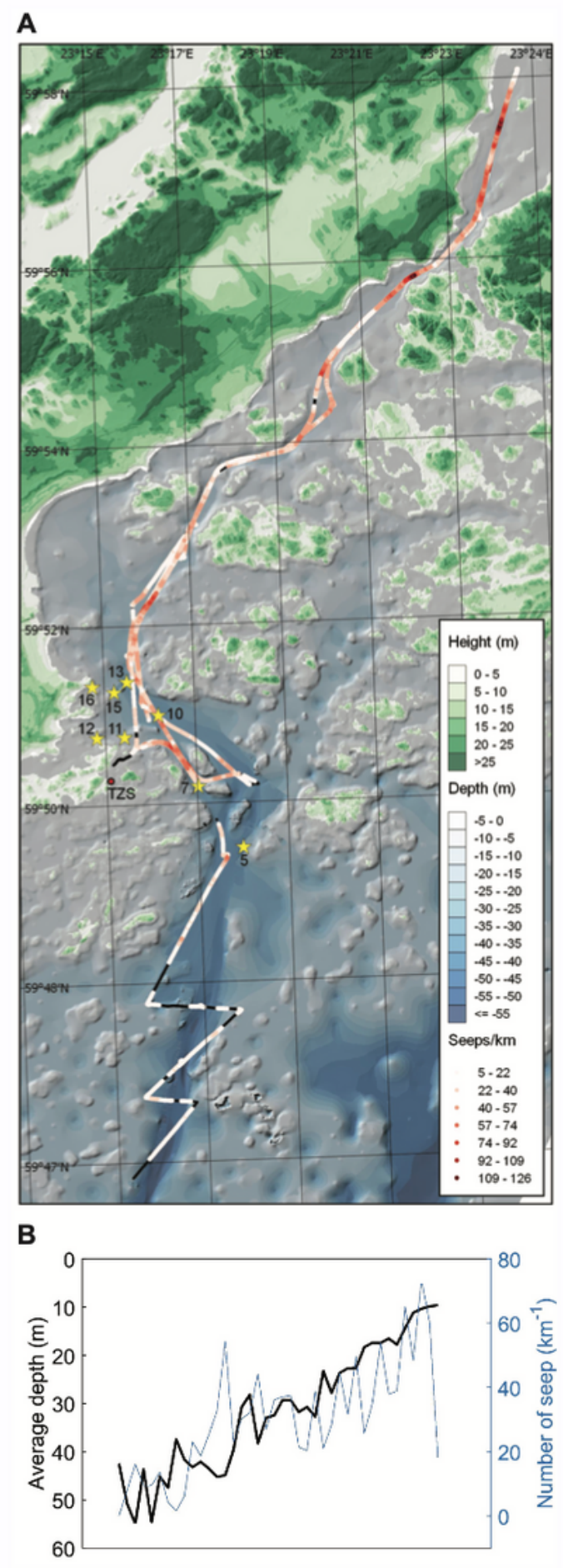

\section{Figure 8}

A) Shows the cruise track and amount of $\mathrm{CH} 4$ seeps $\mathrm{km}-1$ (red colour gradient) observed with acoustic data in the bottom water above the sediment. Black lines on the cruise track denotes no $\mathrm{CH} 4$ seeps observed. The blue gradient denote water depth $(\mathrm{m})$ and the green gradient terrestrial land height $(\mathrm{m})$. B) Water depth (black line, $y$-axis increasing with lower water depth) compared to the amount of $\mathrm{CH} 4$ seeps 
observed (blue line, $\mathrm{y}$-axis increasing with more $\mathrm{CH} 4$ seeps). Stations were sediment were sampled are denoted by star symbols.
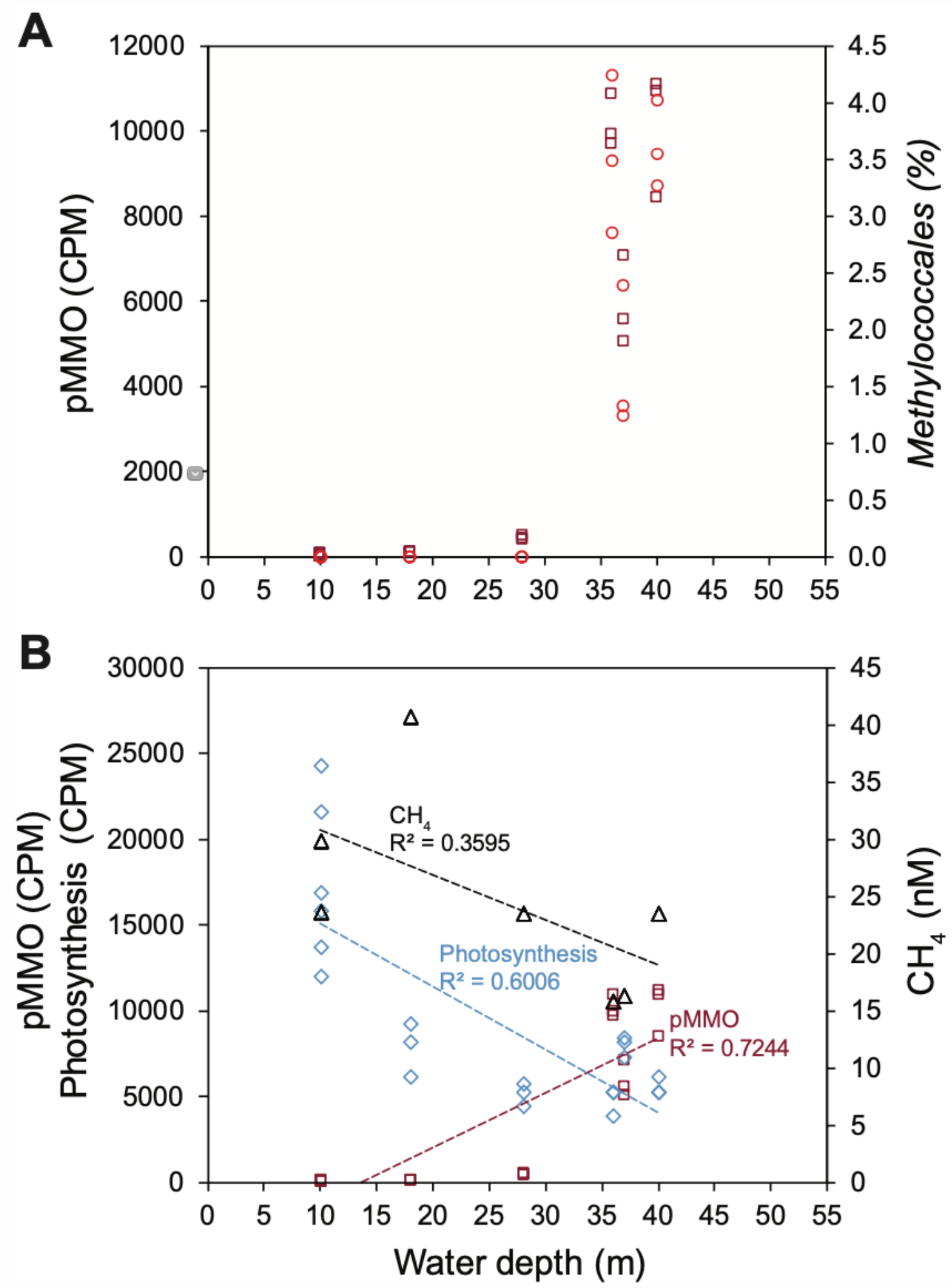

Figure 9

A) The relationship between water depth (x-axis) and the relative abundance (\%) of Methylococcales (16S rRNA gene 2018 DNA data, red) and the enzyme pMMO (RNA data as shown in Fig. 5, CPM, dark red). B) The relationship between water depth and $\mathrm{CH} 4$ concentration in the surface water (black symbols and 
trend line), the enzyme pMMO (CPM, dark red), and the sum of proteins belonging to the $\mathrm{GO}$ category photosynthesis (CPM, light blue).

\section{Supplementary Files}

This is a list of supplementary files associated with this preprint. Click to download.

- AdditionalFile1.docx

- AdditionalFile2.xlsx

- Additionallnformationcaptions.docx 